\title{
A Review: The Bioactivities and Pharmacological Applications of Phellinus linteus
}

\author{
Wenhua Chen ${ }^{1}$, Huiying Tan ${ }^{1}$, Qian Liu ${ }^{1}$, Xiaohua Zheng ${ }^{1}$, Hua Zhang ${ }^{1, *}$, Yuhong Liu ${ }^{1, *}$ and \\ Lingchuan $\mathrm{Xu}$ 1,2,* \\ 1 School of Pharmacy, Shandong University of Traditional Chinese Medicine, Jinan 250355, China; \\ cwh18363032223@163.com (W.C.); 18363036656@163.com (H.T.); cleanlq@163.com (Q.L.); \\ 13465150376@163.com (X.Z.) \\ 2 Key Laboratory of Medicinal Fungi and Resource Development in Shandong Province, Shandong University \\ of Traditional Chinese Medicine, Jinan 250355, China \\ * Correspondence: zhongyiyao77@126.com (H.Z.); liuyuhongwu@126.com (Y.L.); \\ xulingchuan518@sina.com (L.X.); Tel./Fax: +86-531-8962-8081 (L.X.)
}

Received: 6 April 2019; Accepted: 14 May 2019; Published: 16 May 2019

\begin{abstract}
Phellinus linteus is a popular medicinal mushroom that is widely used in China, Korea, Japan, and other Asian countries. P. linteus comprises various bioactive components, such as polysaccharides, triterpenoids, phenylpropanoids, and furans, and has proven to be an effective therapeutic agent in traditional Chinese medicine for the treatment and the prevention of various diseases. A number of studies have reported that $P$. linteus possesses many biological activities useful for pharmacological applications, including anticancer, anti-inflammatory, immunomodulatory, antioxidative, and antifungal activities, as well as antidiabetic, hepatoprotective, and neuroprotective effects. This review article briefly presents the recent progress made in understanding the bioactive components, biological activities, pharmacological applications, safety, and prospects of P. linteus, and provides helpful references and promising directions for further studies of P. linteus.
\end{abstract}

Keywords: Phellinus linteus; polysaccharides; polyphenols; biological activities; pharmacological applications

\section{Introduction}

Phellinus linteus (Berkeley \& M. A. Curtis) Teng is a famous oriental medicinal mushroom, which belongs to Phellinus Quel., Hymenochaetaceae, Aphyllophorales, Hymenomycetes, and Basidiomycetes, and is more commonly known as "sanghuang" in China, "meshimakobu" in Japan, and "sangwhang" in Korea. Its basidiocarps are perennial, pileate, sessile, and usually horseshoe shaped. The pileal surface is dark brown when fresh and becomes black when dried, the pore surface is rusty brown when fresh and becomes brown when dried, the context is brown, and the upper context is a black carapace, and its tubes are cinnamon yellowish-brown when dried (Figure 1). P. linteus is a wood decay fungus that grows on the trunk of Populus Linn., Quercus Linn., Toxicodendron vernicifluum (Stokes) F. A. Barkley, and Morus alba Linn., and the best time for harvesting is from April to May. As a famous mushroom, P. linteus is mainly derived from tropical America, Africa, and East Asia, and it is particularly abundant in China, Japan, and Korea. Additionally, it has been recognized as beneficial to health and an ancient medicine for more than 2000 years [1]. P. linteus was first recorded in Shen Nong's Herbal Classic (Shen Nong Ben Cao Jing), a famous Chinese medical book during the Han dynasty [2]. It has also appeared in many other Chinese medical books, including the New Compendium of Materia Medica (Xin Xiu Ben Cao) and Compendium of Materia Medica (Ben Cao Gang Mu) [3,4]. According to traditional Chinese medicine (TCM) theory, it was believed that P. linteus 
could be used to alleviate sickness in humans by consolidating a channel for hemostasis, removing blood-arthralgia consumption, relieving abdominal pain, and treating chronic diarrhea, among other benefits [5].

P. linteus plays a significant role in promoting health properties. This role has been attributed to the biological activity of its various components, including polysaccharides, triterpenoids, polyphenols, and pyrans. Based on modern pharmacological studies, P. linteus is reported to have multifaceted biological activities, including anti-inflammatory [6-14], immunomodulatory [15-19], antioxidative [20-26], antimicrobial, and antiviral [27-33], as well as anticancer [34-57], antidiabetic [58-67], hepatoprotective [68,69], and neuroprotective [70,71] effects. Among them, polysaccharides with $\beta$-glucan polymers are considered to be among the most important substances and are a potential candidate for developing novel anticancer drugs from natural products [72,73]. Meanwhile, polyphenols of $P$. linteus can also make a significant contribution in terms of their antitumor activity. All of the characterized polyphenols have demonstrated cytotoxic activities against various cancer cells, including pancreatic cancer stem cells, melanoma cells, NB4 human leukemia cells, human epithelial cancer line cells, human nasopharyngeal carcinomas cells, human nasopharyngeal carcinoma cells, hepatic stellate cells, HT29 human colon cancer cells, human breast cancer cells, human colon adenocarcinoma HCT116 cells, embryonic kidney carcinoma A293 cells, multiple myeloma U-266 cells, brain cancer cells, HepG2 cells, and human non-small cell lung carcinoma cells. On the basis of previous research [1,74-77], this paper presents a comprehensive and updated summary of the bioactive components, biological activities, pharmacological applications, possible molecular mechanisms, and safety of $P$. linteus. In a word, it is also our hope that the current review will provide a helpful reference for further study and necessary information for improving the currently available therapeutic agents and dietary supplements of P. linteus.

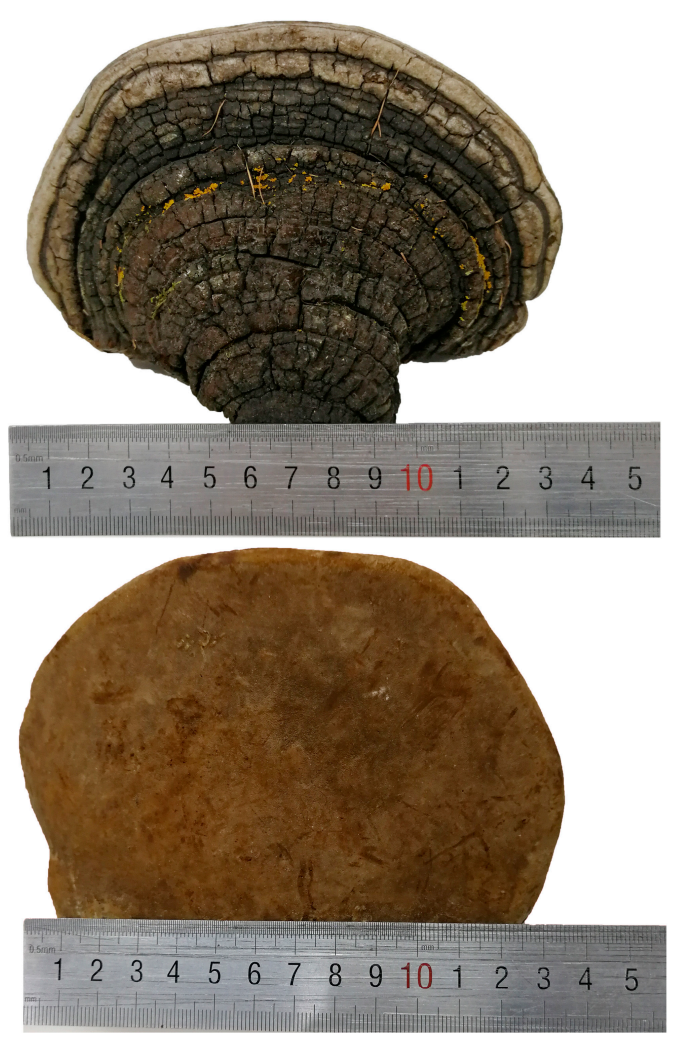

Figure 1. The fruiting body of Phellinus linteus. 


\section{Bioactive Components}

It is obvious that the bioactive components of the fruiting body and the mycelium of P. linteus play a vital part in their biological activities and pharmacological applications. Phenylpropanoids (Figure 2, 1-15), terpenoids (Figure 2, 16-28), furans (Figure 2, 29-32), and others (Figure 2, 33-38) are believed to be the components responsible for the observed biological activities of $P$. linteus. The various groups of compounds have been summarized and are listed in Table 1. The specific chemical structures of these compounds are shown in Figure 2.<smiles>CC(=O)/C=C/c1ccc(O)c(O)c1</smiles>

1<smiles>COc1cc(/C=C/c2ccc(OC)c(OC)c2)oc(=O)c1</smiles>

2<smiles>CC(=O)/C=C/c1ccc(O)c(O)c1</smiles>

3<smiles>CC1CC(=O)/C(=C/c2ccc(O)c(O)c2)O1</smiles>

4

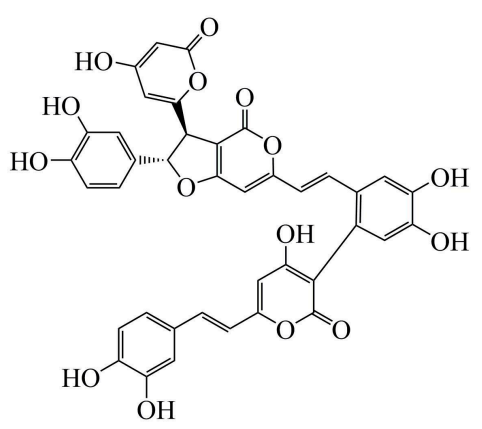

5<smiles>[R]c1cc(/C=C/c2cc3oc(=O)c4cc(O)c(O)cc4c3c(=O)o2)ccc1O</smiles><smiles>O=c1oc(/C=C/c2ccc(O)c(O)c2)cc2oc(-c3ccc(O)c(O)c3)cc12</smiles>

6 R: OH

7 R: H

8

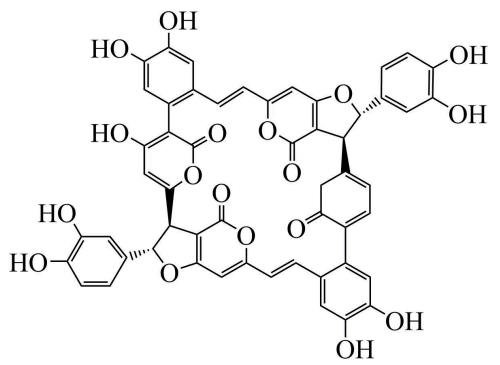

9<smiles>O=C1OC(/C=C/c2ccc(O)c(O)c2)=CC2OC([C@H]3C=CC(O)C(O)C3)C(c3cc(O)cc(=O)o3)C2O1</smiles>

10<smiles>CC(=O)CC(O)[C@@H](Cc1ccc(O)c(O)c1)C1C(=O)OC(C=Cc2ccc(O)c(O)c2)CC1O</smiles>

11

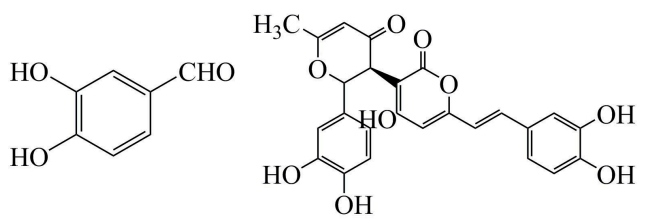

12<smiles>CC1=CC(O)C2(O1)C(c1ccc(O)c(O)c1)OC1C=C(/C=C/c3ccc(O)c(O)c3)OC(=O)C12</smiles>

14<smiles>O=C(O)/C=C/c1ccc(O)c(O)c1</smiles>

15

Figure 2. Cont. 
<smiles>CC1=CC[C@H]([C@H](O)[C@H]2C[C@H]2C(C)(C)O)CC1</smiles>

16<smiles>CC1=C2C[C@H]3C(=O)CCC[C@]3(C)C=C2OC1=O</smiles>

19<smiles>CC(/C=C/[C@H]1[C@H](CO)CCCC1(C)C)=C\C(=O)O</smiles>

25

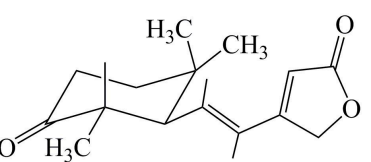

29

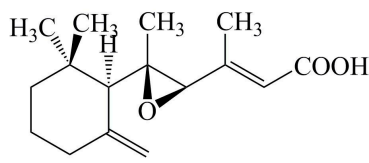

17<smiles>C=C1CCCC(C)(C)[C@@H]1CC/C(C)=C/CO</smiles>

18<smiles>[R]C1C(=C)[C@](C)(/C=C/C(C)=C/C(=O)O)C(C)(C)C([R])C1[R]</smiles>

$21 \mathrm{R}_{1}=\alpha-\mathrm{OH}, \mathrm{R}_{2}=\mathrm{R}_{3}=\mathrm{H}$ $22 \mathrm{R}_{2}=\beta-\mathrm{OH}, \mathrm{R}_{1}=\mathrm{R}_{3}=\mathrm{H}$ $23 \mathbf{R}_{2}=\alpha-O H, R_{1}=R_{3}=H$ $24 \mathrm{R}_{3}=\beta-\mathrm{OH}, \mathrm{R}_{1}=\mathrm{R}_{2}=\mathrm{H}$<smiles>C=C1CC(O)CC(C)(C)[C@H]1C/C=C(\C)C(=O)O</smiles>

26<smiles>[R]C1CCC(=C)[C@@](C)(CC[C@H](C)C(C(=O)O)C(=O)O)C1(C)C</smiles>

$27 \mathrm{R}=\mathrm{H}$ 28R $=\beta-\mathrm{OH}$<smiles>CO[C@@H]1O[C@H](C(O)CO)/C(=C/c2ccc(CO)o2)C1=O</smiles>

30<smiles>CO[C@H]1O[C@@H]([C@H](O)CO)/C(=C/c2ccc(CO)o2)C1=O</smiles><smiles>O=Cc1ccc(CO)o1</smiles>

32<smiles>C=C1CCCC(C)(C)[C@@H]1/C=C/C(C)=C/C(=O)O</smiles>

36
33

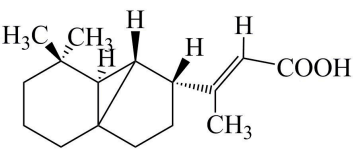<smiles>CC1CC(=O)O[C@@H]1C[C@H]1C(=O)CCCC1(C)C</smiles>

34<smiles>CC(=O)CC(O)/C=C/c1ccc(O)c(O)c1</smiles>

37<smiles>COC(=O)C(C(C)c1cnc(S)[nH]1)[N+](C)(C)C</smiles>

38

Figure 2. Chemical structures of bioactive components isolated from P. linteus. Phenylpropanoids (1-15), terpenoids (16-28), furans (29-32), and others (33-38). 
Table 1. The bioactive components isolated from P. linteus.

\begin{tabular}{|c|c|c|c|c|c|}
\hline No. & Compound Name & Classification & Origin & $\begin{array}{l}\text { Biological } \\
\text { Activity }\end{array}$ & References \\
\hline 1 & 3,4-Dihydroxybenzalacetone & Phenylpropanoid & $\begin{array}{l}\text { Fruiting body of } P . \\
\text { linteus }\end{array}$ & $\begin{array}{l}\text { Anti-inflammatory, } \\
\text { antitumor }\end{array}$ & {$[12,53]$} \\
\hline 2 & Hispidin & Phenylpropanoid & $\begin{array}{l}\text { Mycelium of } P . \\
\text { linteus }\end{array}$ & $\begin{array}{l}\text { Antioxidative, } \\
\text { antitumor, } \\
\text { antidiabetic, } \\
\text { cardioprotective }\end{array}$ & {$[22,23,55,59,61,62,78]$} \\
\hline 3 & Inotilone & Phenylpropanoid & $\begin{array}{l}\text { Mycelium of } P . \\
\quad \text { linteus }\end{array}$ & $\begin{array}{c}\text { Antioxidative, } \\
\text { antiviral }\end{array}$ & {$[24,33]$} \\
\hline 4 & 4-(3,4-Dihydroxyphenyl)-3-buten-2-one & Phenylpropanoid & $\begin{array}{l}\text { Mycelium of } P . \\
\text { linteus }\end{array}$ & $\begin{array}{c}\text { Antioxidative, } \\
\text { antiviral, } \\
\text { gastroprotective }\end{array}$ & {$[24,33,79]$} \\
\hline 5 & Phellinstatin & Phenylpropanoid & $\begin{array}{l}\text { Mycelium of } P . \\
\text { linteus }\end{array}$ & Antimicrobial & [28] \\
\hline 6 & Meshimakobnol A & Phenylpropanoid & $\begin{array}{l}\text { Fruiting body of } P . \\
\text { linteus }\end{array}$ & Antitumor & {$[56,57]$} \\
\hline 7 & Meshimakobnol B & Phenylpropanoid & $\begin{array}{l}\text { Fruiting body of } P . \\
\text { linteus }\end{array}$ & Antitumor & {$[56,57]$} \\
\hline 8 & Phellifuropyranone A & Phenylpropanoid & $\begin{array}{l}\text { Fruiting body of } P \text {. } \\
\text { linteus }\end{array}$ & Antitumor & [57] \\
\hline 9 & Phelligridimer A & Phenylpropanoid & $\begin{array}{l}\text { Fruiting body of } P . \\
\text { linteus }\end{array}$ & Antidiabetic & [65] \\
\hline 10 & Hypholomine B & Phenylpropanoid & $\begin{array}{l}\text { Fruiting body of } P . \\
\text { linteus }\end{array}$ & Antidiabetic & [65] \\
\hline 11 & Interfungin $\mathrm{A}$ & Phenylpropanoid & $\begin{array}{l}\text { Fruiting body of } P . \\
\text { linteus }\end{array}$ & Antidiabetic & [65] \\
\hline 12 & Protocatechualdehyde & Phenylpropanoid & $\begin{array}{l}\text { Fruiting body of } P . \\
\text { linteus }\end{array}$ & Antidiabetic & {$[65,66]$} \\
\hline 13 & Davallialactone & Phenylpropanoid & $\begin{array}{l}\text { Fruiting body of } P \text {. } \\
\text { linteus }\end{array}$ & Antidiabetic & {$[65,66]$} \\
\hline 14 & Inoscavin $\mathrm{A}$ & Phenylpropanoid & $\begin{array}{l}\text { Fruiting body of } P . \\
\text { linteus }\end{array}$ & Antidiabetic & {$[65,66]$} \\
\hline 15 & Caffeic acid & Phenylpropanoid & $\begin{array}{l}\text { Mycelium of } P . \\
\text { linteus }\end{array}$ & Antioxidative & [24] \\
\hline 16 & Phellilane L & Terpenoid & $\begin{array}{c}\text { Mycelium of } P . \\
\text { linteus }\end{array}$ & Antimicrobial & [29] \\
\hline 17 & Phellidene E & Terpenoid & $\begin{array}{l}\text { Mycelium of } P . \\
\text { linteus }\end{array}$ & Antimicrobial & [30] \\
\hline 18 & $(-)$-trans- $\gamma$-Monocyclofarnesol & Terpenoid & $\begin{array}{l}\text { Mycelium of } P . \\
\text { linteus }\end{array}$ & Antimicrobial & [30] \\
\hline 19 & Atractylenolide I & Terpenoid & $\begin{array}{c}\text { Mycelium of } P . \\
\text { linteus }\end{array}$ & Antitumor & [40] \\
\hline 20 & Phellinulin D & Terpenoid & $\begin{array}{l}\text { Mycelium of } P . \\
\text { linteus }\end{array}$ & Hepatoprotective & [69] \\
\hline 21 & Phellinulin E & Terpenoid & $\begin{array}{c}\text { Mycelium of } P . \\
\text { linteus }\end{array}$ & Hepatoprotective & [69] \\
\hline 22 & Phellinulin F & Terpenoid & $\begin{array}{l}\text { Mycelium of } P . \\
\text { linteus }\end{array}$ & Hepatoprotective & [69] \\
\hline 23 & Phellinulin G & Terpenoid & $\begin{array}{l}\text { Mycelium of } P . \\
\text { linteus }\end{array}$ & Hepatoprotective & [69] \\
\hline 24 & Phellinulin H & Terpenoid & $\begin{array}{c}\text { Mycelium of } P . \\
\text { linteus }\end{array}$ & Hepatoprotective & [69] \\
\hline 25 & Phellinulin I & Terpenoid & $\begin{array}{l}\text { Mycelium of } P . \\
\text { linteus }\end{array}$ & Hepatoprotective & [69] \\
\hline 26 & Phellinulin K & Terpenoid & $\begin{array}{l}\text { Mycelium of } P . \\
\text { linteus }\end{array}$ & Hepatoprotective & [69] \\
\hline 27 & Phellinulin M & Terpenoid & $\begin{array}{l}\text { Mycelium of } P . \\
\text { linteus }\end{array}$ & Hepatoprotective & [69] \\
\hline
\end{tabular}


Table 1. Cont.

\begin{tabular}{|c|c|c|c|c|c|}
\hline No. & Compound Name & Classification & Origin & $\begin{array}{l}\text { Biological } \\
\text { Activity }\end{array}$ & References \\
\hline 28 & Phellinulin N & Terpenoid & $\begin{array}{l}\text { Mycelium of } P . \\
\text { linteus }\end{array}$ & Hepatoprotective & [69] \\
\hline 29 & Phellinone & Furan & $\begin{array}{l}\text { Mycelium of } P . \\
\quad \text { linteus }\end{array}$ & Antimicrobial & [31] \\
\hline 30 & Phellinusfuran A & Furan & $\begin{array}{l}\text { Fruiting body of } P . \\
\text { linteus }\end{array}$ & Anti-complementary & [80] \\
\hline 31 & Phellinusfuran B & Furan & $\begin{array}{l}\text { Fruiting body of } P . \\
\text { linteus }\end{array}$ & Anti-complementary & [80] \\
\hline 32 & 5-Hydroxymethyl-2-furaldehyde & Furan & $\begin{array}{l}\text { Fruiting body of } P . \\
\text { linteus }\end{array}$ & Antidiabetic & [67] \\
\hline 33 & Ellagic acid & Other & $\begin{array}{l}\text { Fruiting body of } P . \\
\text { linteus }\end{array}$ & Antidiabetic & [65] \\
\hline 34 & Phellilin C & Other & $\begin{array}{l}\text { Mycelium of } P . \\
\text { linteus }\end{array}$ & Hepatoprotective & [69] \\
\hline 35 & $\gamma$-Ionylideneacetic acid & Other & $\begin{array}{l}\text { Mycelium of } P . \\
\text { linteus }\end{array}$ & Hepatoprotective & [69] \\
\hline 36 & Phellinulin A & Other & $\begin{array}{l}\text { Mycelium of } P . \\
\text { linteus }\end{array}$ & Hepatoprotective & {$[54,69]$} \\
\hline 37 & Hispolon & Other & $\begin{array}{l}\text { Fruiting body and } \\
\text { mycelium of } P . \\
\text { linteus }\end{array}$ & $\begin{array}{c}\text { Antitumor, } \\
\text { anti-inflammatory }\end{array}$ & {$[7,9,41-43]$} \\
\hline 38 & Ergothioneine & Other & $\begin{array}{l}\text { Mycelium of } P . \\
\quad \text { linteus }\end{array}$ & Antidiabetic & [62] \\
\hline
\end{tabular}

\subsection{Phenylpropanoids}

Phenylpropanoids are the most representative and predominant type of bioactive constituent in the fruiting body and the mycelium of $P$. linteus with verified anti-inflammatory [12], antioxidative [24], antitumor [53,55-57], antidiabetic [59,61,62,65-67], antimicrobial [28], antiviral [33], and anti-complementary activity [80], as well as cardioprotective [78] and gastroprotective [79] effects. Among them, 3,4-dihydroxybenzalacetone (1) from the fruiting body of P. linteus was reported to show anti-inflammatory activity [12]. It was reported that 3, 4-dihydroxybenzalacetone (1), hispidin (2), meshimakobnol A (6), meshimakobnol B (7), and phellifuropyranone A (8) showed antitumor effects in vitro and in vivo [53,55-57]. Some previous studies have indicated that hispidin (2), inotilone (3), 4-(3,4-dihydroxyphenyl)-3-buten-2-one (4), and caffeic acid (15) from the mycelium of $P$. linteus exhibited antioxidative activities [23,24]. Some articles have also shown that inotilone (3) and 4-(3,4-dihydroxyphenyl)-3-buten-2-one (4) have antiviral activities [33]. Recent studies have revealed that hispidin (2), phelligridimer A (9), hypholomine B (10), interfungin A (11), protocatechualdehyde (12), davallialactone (13), and inoscavin A (14) from the fruiting body of $P$. linteus all showed antidiabetic effects [59,61,62,65-67]. It was reported that phellinstatin (5) displayed antibacterial activity against Staphylococcus aureus and MRSA (Methicillin resistant S. aureus) [28]. In addition, hispidin (2) was reported to have a cardioprotective effect [78]. Furthermore, 4-(3,4-dihydroxyphenyl)-3-buten-2-one (4) was reported to exhibit gastric protective activity [79]. To date, 15 kinds of phenylpropanoid compounds have been isolated from P. linteus with biological activities and pharmacological applications.

\subsection{Terpenoids}

Terpenoids are also the major bioactive constituents of the mycelium of $P$. linteus and are important secondary metabolites. To date, phytochemists have discovered 13 kinds of terpenoids from the mycelium of $P$. linteus with pharmacological activity $[29,30,40,69]$. It was reported that phellilane L (16), phellidene $E(\mathbf{1 7})$, and (-)-trans- $\gamma$-monocyclofarnesol (18) exhibited antimicrobial activities against $P$. gingivalis $[29,30]$. In addition, atractylenolide I (19) was revealed to have antitumor activity [40]. Furthermore, phellinulin D (20), phellinulin E (21), phellinulin F (22), phellinulin G (23), phellinulin 
$\mathrm{H}$ (24), phellinulin I (25), phellinulin $\mathrm{K}$ (26), phellinulin $\mathrm{M}$ (27), and phellinulin $\mathrm{N}$ (28) isolated from the mycelium of $P$. linteus were indicated to have a hepatoprotective effect [69]. Furthermore, the chemical structure of terpenoid components is clearly correlated with pharmaceutical activities, and this relationship will be the subject of increasing research attention in the future.

\subsection{Furans}

Furans, a kind of pentacyclic compound containing oxygen, are an intermediate of synthetic drugs. Studies have demonstrated that phellinone (29) from the mycelium of $P$. linteus exhibited antimicrobial activities [31]. It has also been reported that phellinusfuran A (30) and phellinusfuran B (31) from the fruiting body of P. linteus showed anti-complementary activity [80]. Additionally, 5-hydroxymethyl-2-furaldehyde (32) from the fruiting body of P. linteus was shown to have antidiabetic effects [67].

\subsection{Others}

Ellagic acid (33) from the fruiting body of P. linteus was shown to have antidiabetic effects [65]. Phellilin C (34), $\gamma$-ionylideneacetic acid (35), and phellinulin A (36) from the mycelium of P. linteus exhibited a hepatoprotective effect [54,69]. Hispolon (37) from the mycelium of $P$. linteus exhibited anti-inflammatory activity [7,9]. Meanwhile, hispolon (37) from the fruiting body of $P$. linteus also showed antitumor activity [42]. In addition, ergothioneine (38) from the mycelium of P. linteus was reported to exhibit antidiabetic activity [62].

\section{Biological Activities}

\subsection{Anti-Inflammatory Activities}

Published reports have consistently indicated that some mushroom extracts exhibit anti-inflammatory effects. Furthermore, the bioactivities of medicinal and edible mushrooms have been shown to possess anti-inflammatory activity through suppression of the production of different types of inflammatory mediators $[81,82]$. Studies have shown that $n$ - $\mathrm{BuOH}$ extracts from the fruiting body of $P$. linteus have anti-inflammatory activity through the inhibition of nitric oxide (NO), nitric oxide synthase (iNOS), and matrix metalloproteinase-9 (MMP-9) expression. These suppress the phosphorylation of protein kinase $\mathrm{C} \delta / \mathrm{NF}-\mathrm{E} 2-$-related factor 2 ( $\mathrm{PKC} / \mathrm{Nrf2}$ )/antioxidant response element (ARE) signaling to upregulate the expression of heme-oxygenase-1 (HO-1) in lipopolysaccharide (LPS)-induced RAW264.7 macrophages in a time-dependent manner [6]. Several groups showed that hispolon (50, $100,200,400 \mu \mathrm{g} / \mathrm{mL}$ ) from the mycelium of $P$. linteus possessed the greatest inhibitory effects against LPS-induced inflammatory mediators through suppressing the nuclear factor kappa beta (NF- $\mathrm{kB}$ ) signaling pathway by reducing the expression of iNOS, NO, tumor necrosis factor (TNF)- $\alpha$ in RAW 264.7 cells, and murine primary peritoneal exudate macrophages (PEMs) [7]. Several in vitro and in vivo models stimulated by LPS and dextran sodium sulfate (DSS) from the mycelium of P. linteus extracts exhibited an anti-inflammatory effect through inhibiting the NF- $\mathrm{KB}$ and the mitogen-activated protein kinase (MAPK) signaling pathway by reducing the expression of iNOS, cyclooxygenase-2 (Cox-2), extracellular regulated protein kinase (ERK), and p38 [8]. Recent reports have indicated that hispolon of $P$. linteus inhibited LPS and lipoteichoic acid (LTA)-induced inducible iNOS/NO production through upregulating the HO-1 and downregulating the JNK/NF- $\mathrm{KB}$ signaling pathways in a time- and dose-dependent manner $[9,10]$. Studies have shown that ethyl acetate extracts $(0-200$ $\mu \mathrm{g} / \mathrm{mL}$ ) from the mycelium of $P$. linteus could inhibit $\beta$-hexosaminidase release and the activation of spleen tyrosine kinase (Syk), GRB2-associated-binding protein 2 (Gab2), and ERK expression in immunoglobulin E (IgE)/Ag-induced RBL-2H3 cells. It was also demonstrated that ethyl acetate extracts of $P$. linteus could inhibit LPS-induced NO production and pro-inflammatory cytokines in RAW 264.7 cells [11]. Moreover, 3,4-Dihydroxybenzalacetone (DBL) $(5 \mathrm{mg} / \mathrm{kg})$ from the fruiting body of $P$. linteus was reported to suppress the activation of MAPK and NF- $\mathrm{kB}$ by inhibiting the expression 
of Toll-like receptor 4 (TLR4) and phosphoinositide-3-kinase (PI3K)/AKT [12]. In addition, DBL not only markedly suppressed the protein expression of iNOS, COX-2, TNF- $\alpha$, interleukin-1 $\beta$ (IL-1 $\beta$ ), interleukin-6 (IL-6), MMP-2, and MMP-9, but also increased the expression of antioxidative enzymes such as superoxide dismutase (SOD), catalase, and glutathione peroxidase (GPx) [12]. The results indicated that DBL exhibited significant anti-inflammatory activity on LPS-induced acute lung injuries in mice. Many pharmacological studies have shown that polysaccharides $(500 \mathrm{mg} / \mathrm{kg} / \mathrm{d})$ of $P$. linteus could markedly decrease the expression of inflammatory cytokines of IL-6, IL-1 $\beta$, TNF- $\alpha$, and iNOS in DSS-induced mice [13]. Another experiment indicated that polysaccharides $(0-100 \mu \mathrm{g} / \mathrm{mL})$ of $P$. linteus had potent anti-inflammatory activity through regulating the MAPK and the PPAR signaling pathways by reducing the level of TNF- $\alpha$, IL-1 $\beta$, IL-6, NF- $\mathrm{kB}$, activator protein-1 (AP-1), COX-2, iNOS, ERK1/2, p38, and JNK in LPS-induced RAW 264.7 macrophages [13]. Furthermore, it was reported that polysaccharides $(0,50,100,200 \mu \mathrm{mol} / \mathrm{L})$ of $P$. linteus treated for 24,48 , and $72 \mathrm{~h}$ could downregulate the production of the pro-inflammatory cytokines of TNF- $\alpha$, IL-1 $\beta$, IL-2, IL-6, and IL-12, and upregulate the anti-inflammatory cytokines IL-4 and IL-10 through inhibiting the translocation of NF- $\mathrm{KB}$ in LPS-stimulated RAW264.7 macrophages [14]. All in all, the anti-inflammatory activities of P. linteus are closely related to the inhibition of pro-inflammatory mediators through the activation of the HO-1 signaling pathway and downregulation of the JNK-NF-KB-AP-1, reactive oxygen species (ROS), MAPK, and peroxisome proliferator-activated receptor (PPAR) signaling pathways. These anti-inflammatory effects suggest that $P$. linteus might hold promise for the treatment of inflammatory diseases.

\subsection{Immunomodulatory Activities}

Some articles have shown that proteoglycan $(0-500 \mu \mathrm{g} / \mathrm{mL})$ from the fruiting body of $P$. linteus could enhance the expression of co-stimulatory molecules, CD80 and CD86, as well as the proliferation rates in $B$ lymphocytes. The protein tyrosine kinase (PTK) and the protein kinase $\mathrm{C}(\mathrm{PKC})$ signaling pathways are also considered to be involved in the mechanism of these immunomodulatory activities [15]. A study confirmed that crude polysaccharides $(200 \mathrm{mg} / \mathrm{kg}$ ) from the fruiting body of $P$. linteus treated for four weeks exhibited immunostimulatory activity through enhancing the Th1-derived cytokine interferon- $\gamma$ (IFN- $\gamma$ ) by T lymphocytes [16]. Another study demonstrated that a novel polysaccharide-protein complex extracted from $P$. linteus was an important biological response modifier of macrophages and NK cells and increased the proliferation of B cells in vitro [17]. It is well known that polysaccharides from $P$. linteus show strong immunomodulatory activity. One study showed that polysaccharides $(100 \mu \mathrm{g} / \mathrm{mL})$ from P. linteus treated for 6 and $24 \mathrm{~h}$ significantly decreased TNF- $\alpha$, stimulated IL-10, and suppressed IL-6 [18]. A further study also reported that polysaccharides $(50,100,200,400 \mu \mathrm{g} / \mathrm{mL})$ from P. linteus treated for $24 \mathrm{~h}$ could regulate the T helper 1 (Th1)/T helper 2 (Th2) balance through decreasing IFN- $\gamma / \mathrm{IL}-4$ for the development of immunomodulatory efficacy [19]. However, the detailed mechanisms underlying this effect of $P$. linteus should be further explored.

\subsection{Antioxidative Activities}

The research conducted thus far has confirmed that extracts of $P$. linteus exhibit strong antioxidative activity in vitro and in vivo. Previous studies have found that polysaccharides $(0.0625 \mathrm{mg} / \mathrm{mL})$ of $P$. linteus treated for $2 \mathrm{~h}$ significantly attenuated tacrine-induced hepatotoxicity and mitochondria dysfunction by an antioxidant protective mechanism through reducing the production of ROS in HepG2 cells [20]. Wang et al. [21] evaluated the antioxidative activities of polysaccharides from the mycelium of $P$. linteus using the 1,1-diphenyl-2-picrylhydrazyl (DPPH) radical-scavenging activity, the Trolox-equivalent antioxidative capacity (TEAC), the ferric reducing ability of plasma (FRAP), and the cytoprotection tests in vitro. The antioxidative assays showed that the strong DPPH radical-scavenging capacities and the antioxidative activities occurred in a dose-dependent manner [21]. Some studies have revealed the antioxidative activity of the hispidin of P. linteus using DPPH, 2,2'-azino-bis(3-ethylbenzothiazoline-6-sulfonic acid) diammonium salt (ABTS), FRAP, hydroxyl radicals, and superoxide anion radicals assays. Therefore, hispidin of $P$. linteus could alleviate 
acrylamide-induced oxidative stresses through decreasing the ROS and the MMP and increasing glutathione (GSH) in Caco-2 cells, exhibiting potential antioxidative activity [22]. Another investigation reported that hispidin derivatives of $P$. linteus displayed notable free radical-scavenging activity. Theoretical results showed that the parameter of double bond dissociation enthalpy $\left(\mathrm{BDE}_{\mathrm{d}}\right)$ plays a central role in assessing the antioxidative activity values of hispidin derivatives [23]. Thermodynamic and kinetic investigations showed that the proton-coupled electron transfer (PCET) mechanism was associated with hispidin derivatives to scavenge free radicals [23]. Recently, some studies revealed that caffeic acid, inotilone, and 4-(3,4-dihydroxyphenyl)-3-buten-2-one (0.1-1 mM) from the mycelium of $P$. linteus showed dose-dependent antioxidative effects in ABTS and DPPH radical-scavenging activity assays, while phellilane $\mathrm{H},(2 \mathrm{E}, 4 \mathrm{E})-(+)-4^{\prime}$-hydrox did not have any effects [24]. Yan et al. [25] revealed that the dose-dependent anti-aging activity of polysaccharides of $P$. linteus was closely related to the antioxidative activity in D-galactose-induced aging model mice. The results showed that polysaccharides $(100,200$, and $400 \mathrm{mg} / \mathrm{kg}$ ) of $P$. linteus treated for 40 days markedly increased the activity of SOD, catalase (CAT), and GSH-Px, and significantly reduced the malondialdehyde (MDA) content of serum and livers [25]. Administration of 300,600, and $1200 \mathrm{mg} / \mathrm{kg} / \mathrm{d}$ chitosan oligosaccharide (a natural polysaccharide) to aged rats induced using D-galactose $(250 \mathrm{mg} / \mathrm{kg} / \mathrm{d})$ for eight weeks significantly increased the activity of CAT, GSH-Px, and SOD and decreased the content of MDA [26]. These results have revealed that the polysaccharides of $P$. linteus demonstrate marked anti-aging activity through increasing the antioxidant defenses and decreasing oxidative stress. Therefore, these findings indicate that $P$. linteus extracts may have potential as antioxidative agents.

\subsection{Antimicrobial and Antiviral Activities}

Hur et al. [27] revealed the antibacterial activity of different solvent extracts of $P$. linteus against 12 methicillin-resistant $S$. aureus stains. The results demonstrated that the $n$ - $\mathrm{BuOH}$ fractions of P. linteus methanol extracts exhibited potent antimicrobial activity for all tested stains, with minimum inhibitory concentration (MIC) values ranging from 63 to $125 \mu \mathrm{g} / \mathrm{mL}$ [27]. In another study, a new trimeric hispidin derivative from the mycelium of $P$. linteus, phellinstatin, was reported to possess antibacterial properties [28]. The results suggested that phellinstatin significantly inhibited S. aureus enoyl-ACP reductase with an $\mathrm{IC}_{50}$ value of $6 \mu \mathrm{g} / \mathrm{mL}$ and exhibited potent antimicrobial activities against $S$. aureus and MRSA. An evaluation of the antimicrobial activity of phellilane L-isolated from the medicinal mushroom of P. linteus - against the periodontal bacteria Porphyromonas gingivalis had an MIC value of $278 \mu \mathrm{g} / \mathrm{mL}$, lower than those of hinokitiol and triclosan that were used as positive controls (MIC of 25.0 and $3.13 \mu \mathrm{g} / \mathrm{mL}$, respectively) in an antimicrobial assay [29]. $\gamma$-Ionylidene sesquiterpenoid from the mycelium of $P$. linteus was also shown to have antimicrobial activity against $P$. gingivalis [30]. The results revealed that (-)-trans- $\gamma$-monocyclofarnesol displayed significant antimicrobial activity against $P$. gingivalis with an MIC value of $5.9 \mu \mathrm{g} / \mathrm{mL}$, while $(+)-\gamma$-ionylideneacetic acid and phellidene E had weak effects on the growth of $P$. gingivalis. Phellinone isolated from the mycelium of $P$. linteus was indicated to show antimicrobial activity against Bacillus subtilis IAM 1090 [31]. In addition, previous studies reported that extracts from the mycelium of $P$. linteus showed notable antiviral effects against influenza A virus H5N1 [32]. Inotilone and 4-(3,4-dihydroxyphenyl)-3-buten-2-one exhibited potent, dose-dependent, antiviral activity against $\mathrm{H} 1 \mathrm{~N} 1$ neuraminidase with $\mathrm{IC}_{50}$ values of 29.1 and $125.6 \mu \mathrm{g} / \mathrm{mL}$, respectively [28]. They also exhibited an antiviral effect on influenza A/WS/33 virus with $\mathrm{IC}_{50}$ values of 61.5 and $52.3 \mu \mathrm{g} / \mathrm{mL}$, respectively, with a positive control (oseltamivir $\mathrm{IC}_{50}=64.7$ $\mu \mathrm{g} / \mathrm{mL}$ ) in a viral cytopathic effect reduction assay in MDCK cells [33]. However, the active principle of these extracts and the detailed mechanism responsible for these antimicrobial and antiviral effects should be further investigated. Figure 3 shows all the known biological activities of $P$. linteus and their underlying mechanisms. 


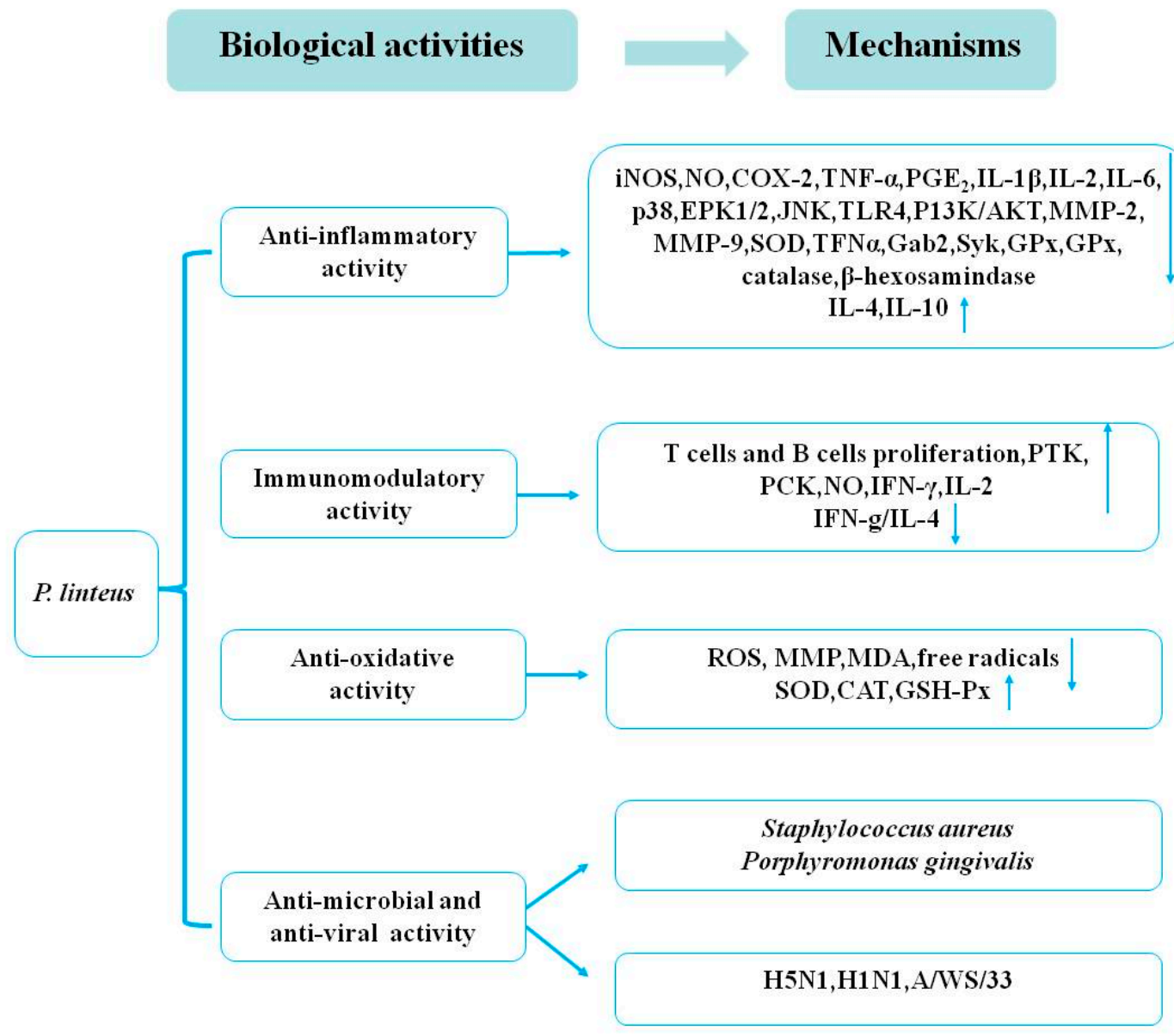

Figure 3. The biological activities of $P$. linteus and their mechanisms.

\section{Pharmacological Applications}

\subsection{Anticancer Effects}

Medicinal mushrooms play an irreplaceable role regarding the therapeutic potential and the development of novel anticancer agents with no side effects. Joseph et al. (2017) revealed that the mechanisms of medicinal mushrooms involve the PI3K/AKT, the Wnt-CTNNB1, and the NF-KB signaling pathways in human cancers [83]. Sliva (2010) reviewed the alternative treatment of cancer using P. linteus [74]. In this review, the anticancer activities of $P$. linteus were summarized and are listed in Tables 2 and 3. The potential anticancer mechanisms of P. linteus are presented in Figure 4.

Table 2. The anticancer activity of polysaccharides, hispolon, or others from P. linteus in vitro studies.

\begin{tabular}{ccccc}
\hline No. $\begin{array}{c}\text { Polysaccharides, } \\
\text { Hispolon, or Others }\end{array}$ & Model & Dose & Results \\
\hline 1 & Polysaccharides & $\begin{array}{c}\text { Human colorectal } \\
\text { carcinoma (HT29) } \\
\text { cells }\end{array}$ & $\begin{array}{c}25,50,100,200 \\
\mu \mathrm{g} / \mathrm{mL}\end{array}$ & $\begin{array}{c}\text { Polysaccharides had an inhibitory effect on the } \\
\text { proliferation of HT29 cells by blocking the cell cycle } \\
\text { in S-phase and downregulation of the expression of } \\
\text { cyclin D1, cyclin E, and cyclin-dependent kinases } \\
\text { (CDK2), and increased upregulation of the } \\
\text { expression of P27kip1 in vitro. }\end{array}$ \\
\hline [34] & HepG2 cells & $\begin{array}{c}\text { Polysaccharides had an inhibitory effect on the } \\
\text { proliferation of HepG2 cells by blocking tumor cells } \\
\text { going into the S-phase, upregulating the expression } \\
\text { of P27kip1 and cyclin A, and downregulating the } \\
\text { expression of calreticulin, cyclin D1, cyclin E, and } \\
\text { CDK2 in vitro. }\end{array}$ \\
\hline [35]
\end{tabular}


Table 2. Cont.

\begin{tabular}{|c|c|c|c|c|c|}
\hline No. & $\begin{array}{l}\text { Polysaccharides, } \\
\text { Hispolon, or Others }\end{array}$ & Model & Dose & Results & References \\
\hline 3 & Polysaccharide (PL-N1) & HepG2 cells & $\begin{array}{l}50,100,200 \\
\mu \mathrm{g} / \mathrm{mL}\end{array}$ & $\begin{array}{l}\text { Polysaccharides had an inhibitory effect on the } \\
\text { growth of HepG2 cells. }\end{array}$ & [36] \\
\hline 4 & $\begin{array}{c}\text { Polysaccharide (PLPS1 } \\
\text { and PLPS-2) }\end{array}$ & S-180 sarcoma cells & $25 \mu \mathrm{g} / \mathrm{mL}$ & $\begin{array}{l}\text { Polysaccharides exhibited strong anticancer activity } \\
\text { against S-180 sarcoma cells. }\end{array}$ & [37] \\
\hline 5 & Polysaccharides & HepG2 cells & $0.5-2.0 \mathrm{mg} / \mathrm{mL}$ & $\begin{array}{l}\text { These results provided information on significant } \\
\text { proteins of hepatocellular carcinoma (HCC). }\end{array}$ & [38] \\
\hline 6 & Polysaccharides & $\begin{array}{c}\text { Colon cancer } \\
\text { HCT116 and HT29 } \\
\text { cells }\end{array}$ & $50 \mu \mathrm{g} / \mathrm{mL}$ & $\begin{array}{l}\text { Polysaccharides could reduce the side effects of } \\
\text { camptothecin } 11 \text { (CPT 11) }(10 \mathrm{ng} / \mathrm{ml}) \text { when they were } \\
\text { used as drug combinations. }\end{array}$ & [39] \\
\hline 7 & $\begin{array}{l}\text { Ethanol extracts, ethyl } \\
\text { acetate extracts, } n \text {-hexane } \\
\text { fractions }\end{array}$ & HT29 cells & $\begin{array}{l}149.9,69.8, \text { and } \\
77.8 \mu \mathrm{g} / \mathrm{mL}\end{array}$ & $\begin{array}{l}\text { Fractions of ethanol, ethyl acetate, and } n \text {-hexane } \\
\text { inhibited the growth of HT29 cell lines. }\end{array}$ & [40] \\
\hline 8 & Hispolon & $\begin{array}{l}\text { NB4 human } \\
\text { leukemia cells }\end{array}$ & $10 \mu \mathrm{g} / \mathrm{mL}$ & $\begin{array}{l}\text { Hispolon inhibited cell proliferation and promoted } \\
\text { cell apoptosis through blocking } \mathrm{G} / \mathrm{G} 1 \text { to } \mathrm{S} \text { transition. }\end{array}$ & [41] \\
\hline 9 & Hispolon & B16-F10 cells & $10 \mu \mathrm{g} / \mathrm{mL}$ & $\begin{array}{l}\text { Hispolon could induce cell apoptosis by increasing } \\
\text { the expression of caspase- }-3,-8 \text {, and }-9 \text {. }\end{array}$ & [42] \\
\hline 10 & Hispolon & $\begin{array}{l}\text { HONE-1 and } \\
\text { NPC-039 human } \\
\text { nasopharyngeal } \\
\text { carcinoma cells }\end{array}$ & $0-100 \mu \mathrm{M}$ & $\begin{array}{l}\text { Hispolon could inhibit cell proliferation and directly } \\
\text { induce cell apoptosis by promoting the } \\
\text { phosphorylation of JNK1/2, ERK1/2, and p38 MAPK } \\
\text { to activate the Csp-3, Csp-8, Csp-9, and Poly } \\
\text { ADP-Ribose Polymerase (PARP) expression in a } \\
\text { dose- and time-dependent manner. }\end{array}$ & [43] \\
\hline 11 & Hispolon & $\begin{array}{l}\text { MCF7 and T47D } \\
\text { human breast cancer } \\
\text { cells }\end{array}$ & $0-100 \mu \mathrm{M}$ & $\begin{array}{l}\text { Hispolon could induce cell apoptosis through } \\
\text { increasing PARP cleavage and decreasing the } \\
\text { expression of Bcl- } 2 \text { and inhibit cell proliferation by } \\
\text { reducing the ER- } \alpha \text { expression at the level of both } \\
\text { mRNA and protein. }\end{array}$ & [44] \\
\hline 12 & Hispolon & $\begin{array}{l}\text { Human colon cancer } \\
\text { cells }\end{array}$ & $25 \mu \mathrm{M}$ & Hispolon could induce cell apoptosis. & [45] \\
\hline 13 & Hispolon & $\begin{array}{l}\text { Human epithelial } \\
\text { cancer cells }\end{array}$ & $1-500 \mathrm{mM}$ & $\begin{array}{l}\text { Hispolon could inhibit cell proliferation through } \\
\text { repressing the transforming growth factor } \beta \\
\text { (TGF- } \beta \text { )-Snail/Twist signaling pathway of } \\
\text { epithelial-mesenchymal transition (EMT). }\end{array}$ & [46] \\
\hline 14 & Hispolon & $\begin{array}{l}\text { Glioblastoma } \\
\text { U87MG cells }\end{array}$ & $25,50 \mu \mathrm{M}$ & $\begin{array}{l}\text { Hispolon significantly inhibited the tumor cell } \\
\text { proliferation and promoted cell apoptosis. }\end{array}$ & [47] \\
\hline 15 & Ethanol extracts & $\begin{array}{l}\text { B16F10 melanoma } \\
\text { cells }\end{array}$ & $250-500 \mu \mathrm{g} / \mathrm{mL}$ & $\begin{array}{l}\text { Ethanol extracts had antiproliferative activity against } \\
\text { B16F10 melanoma cells through inducing G0/G1 cell } \\
\text { cycle arrest through decreasing cyclin D1 and CDK2 } \\
\text { expression and inducing p21. }\end{array}$ & [48] \\
\hline 16 & Extracts & $\begin{array}{c}\text { PC-3, DU-145, } \\
\text { LNCaP, } \\
\text { T24, ACHN, A549, } \\
\text { MCF-7, AGS, HepG2, } \\
\text { and U-87 cancer cells }\end{array}$ & $0-700 \mu \mathrm{g} / \mathrm{mL}$ & $\begin{array}{l}\text { Extracts could induce apoptosis through oxidative } \\
\text { stress by stimulating Csp-3 and Csp-9 in varieties of } \\
\text { human malignancies, compared with the untreated } \\
\text { control. }\end{array}$ & [49] \\
\hline 17 & Aqueous extracts & $\begin{array}{l}\text { MDA-MB- } 231 \text { breast } \\
\text { cancer cells }\end{array}$ & $40 \mathrm{mg} / \mathrm{mL}$ & $\begin{array}{l}\text { Aqueous extracts exhibited an antiproliferative effect } \\
\text { with an IC } \text { I }_{50} \text { value of } 40 \mathrm{mg} / \mathrm{mL} \text { in a dose-dependent } \\
\text { manner (control: } 10 \mu \mathrm{g} / \mathrm{mL} \text {-flurouracil (5-FU). }\end{array}$ & [50] \\
\hline 18 & Ethanol extracts & $\begin{array}{l}\text { G12VKRAS mutant } \\
\text { colon cancer cells }\end{array}$ & $100 \mu \mathrm{g} / \mathrm{mL}$ & $\begin{array}{l}\text { Ethanolic extracts and cetuximab }(10,30 \mu \mathrm{g} / \mathrm{mL}) \\
\text { were combined, and treatment for three days } \\
\text { inhibited G12VKRAS mutant colon cancer cells by } \\
\text { inducing apoptosis. }\end{array}$ & [51] \\
\hline 19 & 3,4-Dihydroxybenzalactone & $\begin{array}{l}\text { Human non-small } \\
\text { cell lung carcinoma } \\
\text { A } 549 \text { cells }\end{array}$ & $\begin{array}{l}0,6.25,12.5,25 \\
50 \mu \mathrm{M}\end{array}$ & $\begin{array}{l}\text { 3,4-Dihydroxybenzalactone inhibited migratory and } \\
\text { invasive abilities of cancer cells. }\end{array}$ & [53] \\
\hline 20 & Phellinulin A & $\begin{array}{l}\text { Rat hepatic stellate } \\
\text { cells }\end{array}$ & $40 \mu \mathrm{M}$ & $\begin{array}{l}\text { Phellinulin A had significant inhibitory and } \\
\text { therapeutic effects. }\end{array}$ & [54] \\
\hline 21 & Atractylenolide I & $\begin{array}{l}\text { HT29 human colon } \\
\text { cancer cells }\end{array}$ & $0-100 \mu \mathrm{g} / \mathrm{mL}$ & $\begin{array}{l}\text { Atractylenolide I had good preventive and } \\
\text { therapeutic effects. }\end{array}$ & [40] \\
\hline 22 & Hispidin & $\begin{array}{l}\text { BxPC-3 pancreatic } \\
\text { cancer cells and } \\
\text { CSCs }\end{array}$ & $50,100,150 \mu \mathrm{M}$ & $\begin{array}{l}\text { Hispidin had therapeutic potential against BxPC-3 } \\
\text { pancreatic cancer cells and Cancer stem cells (CSCs) } \\
\text { by downregulating the expression of NF-kB, in vitro, } \\
\text { in a dose-dependent manner. }\end{array}$ & [55] \\
\hline 23 & $\begin{array}{l}\text { Phellifuropyranone, } \\
\text { meshimakobnol A and } \\
\text { meshimakobnol B }\end{array}$ & $\begin{array}{l}\text { Mouse melanoma } \\
\text { cells and human } \\
\text { lung cancer cells }\end{array}$ & $\begin{array}{c}5.6-31.3 \mu \mathrm{M}, \\
7.1-22.6 \mu \mathrm{M} \\
\text { and } 6.1-15.0 \\
\mu \mathrm{M}\end{array}$ & $\begin{array}{l}\text { Phellifuropyranone, meshimakobnol A, and } \\
\text { meshimakobnol B exhibited antiproliferative activity } \\
\text { against mouse melanoma cells and human lung } \\
\text { cancer cells in vitro. }\end{array}$ & {$[56,57]$} \\
\hline
\end{tabular}


Table 3. The anticancer activity of polysaccharides, hispolon, or others from P. linteus in vivo studies.

\begin{tabular}{|c|c|c|c|c|c|}
\hline No. & $\begin{array}{l}\text { Polysaccharides, } \\
\text { Hispolon, or Others }\end{array}$ & Model & Dose & Results & References \\
\hline 1 & Polysaccharides & $\begin{array}{l}\text { HT29 cells -bearing } \\
\text { mouse }\end{array}$ & $\begin{array}{l}100,200 \\
\mathrm{mg} / \mathrm{kg} / \mathrm{d}\end{array}$ & $\begin{array}{l}\text { Polysaccharides had an inhibitory effect on tumor } \\
\text { growth in a human colorectal carcinoma cell } \\
\text { (HT29)-bearing mouse in vivo. }\end{array}$ & [34] \\
\hline 2 & Polysaccharides & $\begin{array}{l}\text { HepG2 cells bearing } \\
\text { mouse }\end{array}$ & $100,200 \mathrm{mg} / \mathrm{kg}$ & $\begin{array}{l}\text { Polysaccharides had an inhibitory effect on tumor } \\
\text { growth in a HepG2 cell-bearing mouse in vivo. }\end{array}$ & [35] \\
\hline 3 & Ethanol extracts & C57BL6 mice & $300 \mathrm{mg} / \mathrm{kg} / \mathrm{d}$ & $\begin{array}{l}\text { Ethanol extracts reduced tumor weight and } \\
\text { increased life span (ILS } \%=50.88 \% \text { ) compared with } \\
\text { the tumor control group. }\end{array}$ & [48] \\
\hline 4 & Ethanol extracts & $\begin{array}{l}\text { Tumor-xenografted } \\
\text { mouse }\end{array}$ & $400 \mathrm{mg} / \mathrm{kg} / \mathrm{d}$ & $\begin{array}{l}\text { Ethanol extracts could inhibit the proliferation with a } \\
\text { tumor-xenografted mouse model compared with the } \\
\text { cetuximab }(10,30 \mathrm{mg} / \mathrm{kg} / \mathrm{d}) \text { control group. }\end{array}$ & [51] \\
\hline 5 & Water extracts & $\begin{array}{l}\text { Pancreatic cancer } \\
\text { patients }\end{array}$ & $\begin{array}{l}1100 \mathrm{mg} 3 \\
\text { times per day }\end{array}$ & $\begin{array}{l}\text { Water extracts could assist the chemotherapy } \\
\text { treatment of pancreatic ductal adenocarcinoma, } \\
\text { which improved patient survival. }\end{array}$ & [52] \\
\hline
\end{tabular}

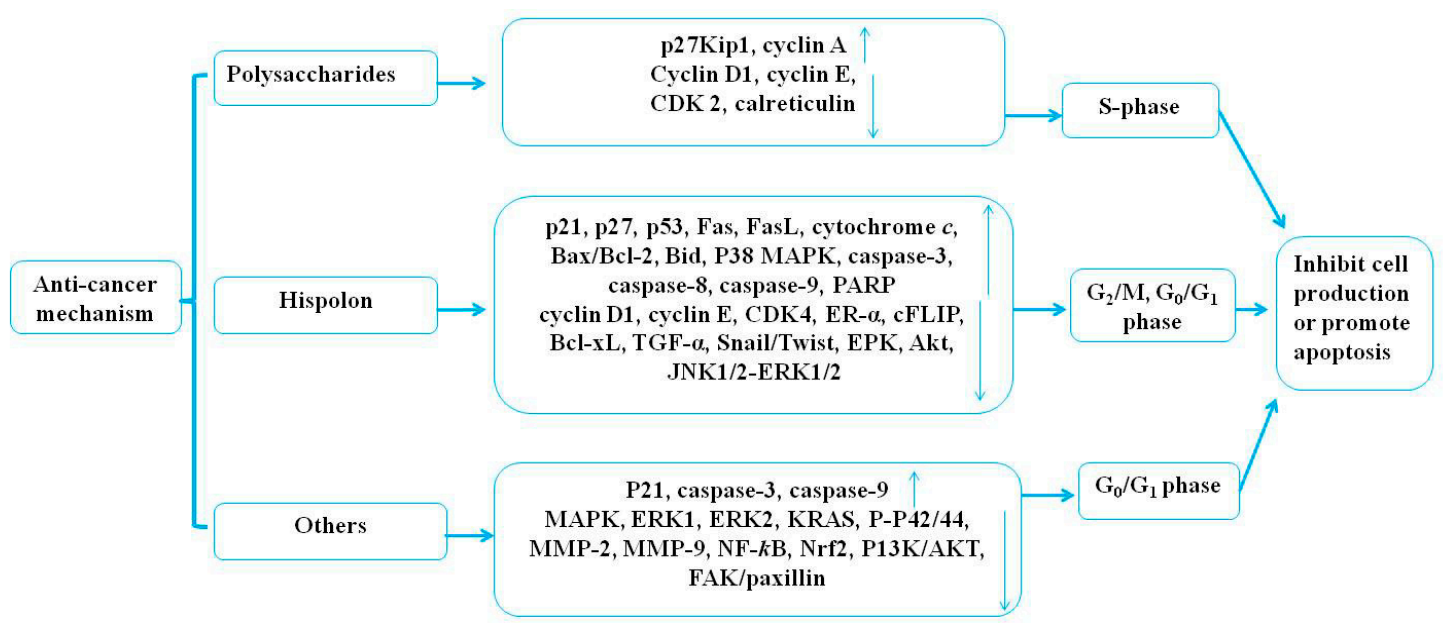

Figure 4. The potential anticancer mechanisms of $P$. linteus.

\subsubsection{The Anticancer Effect of Polysaccharides}

It has been known for centuries that the polysaccharides of medicinal mushrooms are the agents responsible for the observed anticancer properties. Wang et al. (2017) indicated that the bioactivity of the mushroom polysaccharides exhibits a close relationship with the structure of monosaccharide composition and the biosynthesis pathway [84]. A series of studies have shown that mushroom polysaccharides with $\beta$-glucans, $\beta$ - $(1 \rightarrow 3)$ linkages, and water solubility exhibit more anticancer ability $[72,73]$. The proposed mechanism by which mushroom polysaccharides exert their antitumor effect includes cancer-preventing activity, immuno-enhancing activity, and direct tumor-suppressing activity [85].

The polysaccharides of $P$. linteus have shown anticancer activities both in vitro and in vivo. One study found that polysaccharides $(100,200 \mathrm{mg} / \mathrm{kg} / \mathrm{d})$ of $P$. linteus treated for 30 days significantly inhibited tumor growth in a human colorectal carcinoma cell (HT29)-bearing mouse model in vivo compared with saline $(0.2 \mathrm{~mL} / \mathrm{d})$ as a negative control and cisplatin $(2 \mathrm{mg} / \mathrm{kg} / \mathrm{d})$ as a positive control [34]. Compared with the untreated control, polysaccharides $(25,50,100,200 \mu \mathrm{g} / \mathrm{mL})$ from the fresh fruiting body of $P$. linteus treated for 1.5 to $48 \mathrm{~h}$ significantly inhibited the proliferation of HT29 by blocking the cell cycle in S-phase and downregulating the expression of cyclin D1, cyclin E, and cyclin-dependent kinases (CDK2) with increased upregulation of P27kip1 expression in a dose-dependent manner but with no contribution to apoptosis and autophagy [34]. Some other studies have also shown that polysaccharides $(50,100,200 \mu \mathrm{g} / \mathrm{mL})$ from the fresh fruiting body of $P$. linteus treated for 24,48 , and $72 \mathrm{~h}$ caused significant inhibition of HepG2 cell proliferation in a dose-dependent manner $\left(48 \mathrm{~h}, \mathrm{IC}_{50}=125\right.$ $\mu \mathrm{g} / \mathrm{mL}$ ). Furthermore, administration of 100 and $200 \mathrm{mg} / \mathrm{kg}$ of $P$. linteus polysaccharide for 18 days 
showed a significant inhibitory effect on tumor growth in vivo compared with the tumor-bearing (TB) control mice. The results have generally indicated that polysaccharides of P. linteus exhibit significant antitumor activity against HepG2 through blocking tumor cells going into the $S$ stage, upregulating the expression of P27kip1 and cyclin A, and downregulating the expression of calreticulin, cyclin $\mathrm{D} 1$, cyclin $\mathrm{E}$, and CDK2 in vitro and in vivo, but there is an urgent need to verify whether there is a relationship between this remarkable decrease in CDK2 and induced S-phase arrest [35]. Pei et al. (2013) revealed a novel high molecular weight polysaccharide (PL-N1) $(50,100,200 \mu \mathrm{g} / \mathrm{mL})$ from the mycelium of $P$. linteus composed of arabinose, xylose, glucose, and galactose, and the backbone of PL-N1 was $(1 \rightarrow 4)$-linked $\beta$-D-xylopyranosyl residues; it could inhibit the growth of HepG2 cells in a dose-dependent manner in vitro [36]. Mei et al. (2015) found two novel high molecular weight polysaccharides-PLPS- 1 with a backbone of $\alpha$-D- $\alpha$-Glc $(1 \rightarrow 4)-\alpha$-D-Glc $(1 \rightarrow 6)$ units and PLPS-2 with

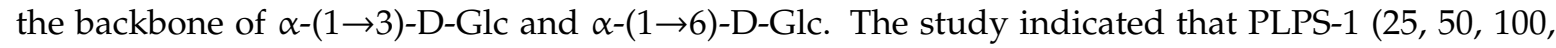
$200 \mu \mathrm{g} / \mathrm{mL}$ ), but not PLPS-2, from the mycelium of $P$. linteus exhibited strong anticancer activity against S-180 sarcoma cells by induction of apoptosis, where 5-fluorouracil (5-Fu) $(25 \mu \mathrm{g} / \mathrm{mL})$ was used as a positive control [37]. Protein-protein interaction (PPI) analysis has indicated that the DJ-1 and the 14-3-3 proteins play important roles in polysaccharide-treated HepG2 cells with $\beta$-actin as a positive control, but whether these proteins can be used for markers of hepatocellular carcinoma (HCC) needs further investigation [38]. The present study showed that the polysaccharides $(50 \mu \mathrm{g} / \mathrm{mL})$ of $P$. linteus could reduce the side effects of camptothecin 11 (CPT 11) $(10 \mathrm{ng} / \mathrm{ml})$ when they were used as a drug combination in colon cancer HCT116 and HT29 cells [39]. It was reported that ethanol extracts, $n$-hexane fractions, and ethyl acetate fractions of $P$. linteus mycelia inhibited the growth of the HT29 cell line in a dose-dependent manner, and the $\mathrm{IC}_{50}$ values were $149.9,69.8$, and $77.8 \mu \mathrm{g} / \mathrm{mL}$, respectively [40]. According to these studies, polysaccharides of $P$. linteus played an important role in producing the observed anticancer activities.

\subsubsection{The Anticancer Effect of Hispolon}

Hispolon, a phenol compound isolated from the fruiting body of P. linteus, plays an important role in facilitating anticancer activity. Recent studies have shown that the apoptotic mechanism of hispolon is to inhibit cell proliferation and promote cell apoptosis through blocking G/G1 to S transition in NB4 human leukemia cells in a time- and dose-dependent manner [41]. The results have indicated that hispolon $(10 \mu \mathrm{g} / \mathrm{mL}, 24 \mathrm{~h})$ of $P$. linteus induced cell arrest through increasing the protein levels of p53, p21, and p27 and reducing the protein levels of cyclin D1, cyclin E, CDK 2, and CDK 4. Furthermore, it could increase the expressions of the extrinsic apoptotic proteins of Fas and FasL, intrinsic proteins of cytochrome $c$, and the ratio of Bax/ Bcl-2 [41]. On the one hand, studies have revealed that hispolon of $P$. linteus could decrease the content of melanin in $\alpha$-melanocyte-stimulating hormone $(\alpha-\mathrm{MSH})$ stimulated through suppressing tyrosinase and the microphthalmia-associated transcription factor (MITF) expression with a concentration of less than $2 \mu \mathrm{g} / \mathrm{mL}$ in B16-F10 cells. On the other hand, it could also induce cell apoptosis by increasing the expression of caspase-3, -8 , and -9 , at concentrations greater than $10 \mu \mathrm{g} / \mathrm{mL}$ in B16-F10 cells, but not in Detroit 551 normal fibroblast cells [42]. In the present study, the studies showed that hispolon $(0-100 \mu \mathrm{M})$ of $P$. linteus could inhibit cell proliferation and directly induce cell apoptosis by promoting the phosphorylation of JNK1/2, ERK1/2, and p38 MAPK to activate Csp-3, Csp-8, Csp-9, and Poly ADP-Ribose Polymerase (PARP) expression in a dose- and time-dependent manner when used on HONE-1 and NPC-039 human nasopharyngeal carcinoma cells [43]. Previous studies have suggested that hispolon $\left(0-100 \mu \mathrm{M} ; \mathrm{IC}_{50}=70 \mu \mathrm{M}\right)$ of $P$. linteus induced cell apoptosis through increasing PARP cleavage and decreasing the expression of Bcl-2. Moreover, it could also inhibit cell proliferation by reducing ER- $\alpha$ expression at the level of both mRNA and protein in MCF7 and T47D human breast cancer cells in vitro, but this needs to be further studied in vivo [44]. Previous reports suggested that hispolon $(70 \mu \mathrm{M})$ of $P$. linteus could promote tumor necrosis factor-related apoptosis-inducing ligand (TRAIL)-induced cell apoptosis through downregulation of the survival proteins of cFLIP, Bcl-2, and $\mathrm{Bcl}-\mathrm{xL}$, with the reactive oxygen 
species-extracellular signal-regulated-kinase-homologous protein (ROS-ERK-CHOP) pathway and upregulation of the expression of Bax and truncated Bid, as well as the death receptors of p53, in a dose- and time-dependent manner. Meanwhile, it could also be sensitive to the expression of caspase 3 , caspase 8, and caspase 9 on human colon cancer cells of HCT116 in vitro [45]. Current studies provide strong evidence that hispolon $\left(1-500 \mathrm{mM} ; \mathrm{IC}_{50}=65 \mu \mathrm{M}\right)$ of $P$. linteus inhibits cell proliferation through repressing the transforming growth factor $\beta$ (TGF- $\beta$ )-Snail/Twist signaling pathway of epithelial-mesenchymal transition (EMT) in human epithelial cancer cells in vitro compared with the untreated control group [46]. Modern pharmacological research has shown that hispolon $(25,50 \mu \mathrm{M})$ of $P$. linteus used for 24,48 , and $72 \mathrm{~h}$ significantly inhibited tumor cell proliferation and promoted cell apoptosis in glioblastoma U87MG cells. Among them, p53 plays a vital role in inducing cell cycle arrest as well as blocking G2/M-phase and reducing the expression of cyclin D4 while increasing the expression of CDK inhibitor p21 compared with a control group [47].

All in all, hispolon of $P$. linteus has been shown to exhibit therapeutic efficacy against various cancer cells, including colorectal, melanoma, leukemia, nasopharyngeal, breast, epithelial, and glioblastoma cancer cells. The mechanism behind the anticancer activities of hispolon of P. linteus anticancer activities works through blocking the cell cycle in $\mathrm{G}_{0} / \mathrm{G}_{1}$-phase or $\mathrm{G}_{2} / \mathrm{M}$-phase through inhibiting cell proliferation and inducing cell apoptosis. Therefore, hispolon is an effective potential anticancer agent, but researchers have only focused on the induction of antiproliferative effects and apoptosis in tumor cells in vitro. Therefore, there is an urgent need to further verify the results by carrying out experiments in vivo.

\subsubsection{The Anticancer Effect of Others}

Medicinal mushrooms, as natural products, have been applied to treat cancer for millennia. Some experts revealed the anticancer activities of ethanol extracts $(300 \mathrm{mg} / \mathrm{kg} / \mathrm{d})$ from the mycelium of P. linteus in combination with Inonotus obliquus, Antrodia camphorata, and Ganoderma lucidum for the Cell Activation Research Institute (CARI III), reducing tumor weight compared with the doxorubicin (Dox)-treated group and increasing life span (ILS \% $=50.88 \%$ ) compared with the tumor control group. The results also indicated that they displayed antiproliferative activity against B16F10 melanoma cells through inducing G0/G1 cell cycle arrest by decreasing cyclin D1 and CDK2 expression and inducing p21 in vitro and in vivo [48]. The present study showed that extracts $(0-700 \mu \mathrm{g} / \mathrm{mL})$ of $P$. linteus could induce apoptosis through oxidative stress by stimulating Csp-3 and Csp-9 in a variety of human malignancies, including prostate cancer metastasized to bone (PC-3), prostate cancer metastasized to brain (DU-145), prostate cancer metastasized to lymph nodes (LNCaP), bladder cancer T24, kidney cancer ACHN, lung cancer A549, breast cancer MCF-7, stomach cancer AGS, liver cancer HepG2, and brain cancer U-87 cells, compared with an untreated control [49]. However, the results did not specify which extracts were used, and further research has been limited. Previous studies revealed that aqueous extracts from the fruiting body of $P$. linteus exhibited a dose-dependent antiproliferative effect, with an $\mathrm{IC}_{50}$ value of $40 \mathrm{mg} / \mathrm{mL}$ in MDA-MB-231 breast cancer cell lines [control: $10 \mu \mathrm{g} / \mathrm{mL}$ 5-flurouracil (5-FU) in vitro] [50]. Ethanolic extracts $(100 \mu \mathrm{g} / \mathrm{mL})$ of P. linteus and cetuximab (10, $30 \mu \mathrm{g} / \mathrm{mL}$ ) that were combined for three days of treatment could work against G12VKRAS mutant colon cancer cells by inducing apoptosis. Therefore, the results have concluded that ethanolic extracts of $P$. linteus significantly improved cetuximab resistance in Kirsten rat sarcoma viral oncogene homolog (KRAS)-mutant colon cancer through modulating the RAS/MAPK pathways by reducing the phosphorylation of MAPK, ERK1, and ERK2 by decreasing the expression of KRAS and p-p42/44 MAPK to promote apoptosis. Further pharmacological experiments have also shown that ethanol extracts from the mycelium of $P$. linteus $(400 \mathrm{mg} / \mathrm{kg} / \mathrm{d})$ treated for 23 days inhibited proliferation with a tumor-xenografted mouse model compared with a cetuximab (10, $30 \mathrm{mg} / \mathrm{kg} / \mathrm{d})$ control group [51]. Moreover, current evidence has indicated that extracts of $P$. linteus administered orally at a dose of $1100 \mathrm{mg}$ three times per day could assist in the chemotherapeutic treatment of pancreatic ductal adenocarcinoma and improve patient survival according to a clinical study of 323 patients from January 
1995 to December 2014. However, well-designed randomized control trials are needed to evaluate and confirm this hypothesis [52]. Previous studies have demonstrated that 3,4-dihydroxybenzalactone (0, $6.25,12.5,25,50 \mu \mathrm{M}$ ) from the fruiting body of $P$. linteus, treated for $24 \mathrm{~h}$ inhibited the migratory and the invasive abilities of cancer cells through suppressing the enzymatic activity of MMP-2 and MMP-9, decreasing the activity of PI3K/AKT, MAPKs, and focal adhesion kinase (FAK)/paxillin, influencing EMT/Snail and Slug, and affecting the NF- $\mathrm{B}$ and Nrf2 signaling pathways in human non-small cell lung carcinoma A 549 cells [53]. Recent studies have found that phellinulin A (40 $\mu \mathrm{M})$ from the mycelium of $P$. linteus had significant inhibitory and therapeutic effects on hepatic fibrosis, especially in activated rat hepatic stellate cells [54]. Numerous recent reports have shown that atractylenolide I $(0-100 \mu \mathrm{g} / \mathrm{mL})$ from the mycelium of $P$. linteus had good preventive and therapeutic effects on HT29 human colon cancer cells and acted in a dose-dependent manner [40]. Recent studies have suggested that hispidin $(50,100,150 \mu \mathrm{M})$ from the mycelium of $P$. linteus treated for 24,48 , and $72 \mathrm{~h}$ had therapeutic potential against BxPC-3 pancreatic cancer cells and cancer stem cells (CSCs) by downregulating the expression of NF-kB in a dose-dependent manner in vitro, and that it exerted a synergistic effect with gemcitabine [55]. Furthermore, phellifuropyranone, meshimakobnol A, and meshimakobnol B isolated from the fruiting body of $P$. linteus exhibited antiproliferative activity against mouse melanoma cells and human lung cancer cells in vitro, with 50\% growth-inhibitory concentrations $\left(\mathrm{GI}_{50}\right)$ of 5.6-31.3, 7.1-22.6, and 6.1-15.0 $\mu \mathrm{M}$, respectively, compared with paclitaxel as a positive control [56,57]. However, the antitumor mechanism underlying this needs to be further examined in animal models.

\subsection{Hypoglycemic Effects}

Some previous studies have indicated that natural health products have potential antidiabetic effects [86]. Kim et al. [58] demonstrated that polysaccharides (30 mg/kg) of P. linteus, as examined every other day from eight to 24 weeks, markedly increased Th2 cytokine production and decreased Th1 cytokine production in a Streptozotocin-induced diabetic animal model. In addition, polysaccharides from the mycelium of $P$. linteus inhibited autoimmune diabetes through reducing the expression of cytokines, including IFN- $\gamma$, IL-2, and TNF- $\alpha$ in Th1 cells and macrophages in vitro [58]. One study confirmed that treatment with hispidin $(70 \mu \mathrm{M})$ from the mycelium of $P$. linteus could not only exhibit potent-free radical-scavenging effects but could also protect MIN6N $\beta$-cells from ROS toxicity through inhibiting cell apoptosis and caspase-3 activity induced by hydrogen peroxide in diabetes [59]. Oral administration with polysaccharides from the mycelium of P. linteus at $100 \mathrm{mg} / \mathrm{kg}$ body weight/d could markedly decrease the level of blood glucose by $35.60 \%$ in alloxan (ALX)-induced diabetic mice [60]. The mechanism of the hypoglycemic effect may be related to the chemical structure of the polysaccharides and needs further study. Another study showed that hispidin $(1-100 \mu \mathrm{M})$ from the mycelium of $P$. linteus treated for $8 \mathrm{~h}$ could exhibit a cytoprotective effect through reducing the expression of Bax, ROS, and NF- $\kappa$ B in palmitate (PA)-induced oxidative stress in C2C12 myotubes, and that it had therapeutic potential as an antidiabetic drug [61]. In vitro studies have indicated that ergothioneine $(2 \mu \mathrm{M})$ and hispidin $(2 \mu \mathrm{M})$ from the mycelium of $P$. linteus had hypoglycemic effects by inhibiting the expression of the NF- $\mathrm{BB}$ signaling pathway through antioxidative activities in rat pheochromocytoma cells compared with positive controls [epalrestat (EPA), $10 \mu \mathrm{M}$; aminoguanidine (AMG), $100 \mathrm{nM}$ ] [62]. Recent studies have demonstrated the underlying molecular mechanisms of polysaccharides of $P$. linteus in the treatment of diabetes mellitus [63]. Polysaccharides $(50 \mathrm{mg} / \mathrm{kg})$ of $P$. linteus examined twice a day for four weeks significantly decreased blood glucose and improved glucose intolerance in male C57BL/6J mice compared with blank and high-fat high-fructose diet (HFD) control groups. In addition, polysaccharides of $P$. linteus ameliorated insulin resistance through regulating hepatic phospholipid metabolism and stimulating insulin signaling transduction [63]. It was reported that polysaccharides $(300,600 \mathrm{mg} / \mathrm{kg})$ from the mycelium of $P$. linteus treated for eight weeks efficiently decreased the blood glucose level and increased insulin resistance and glycogen in an HFD-induced $(120 \mathrm{mg} / \mathrm{kg})$ storage and low-dose streptozotocin (STZ) (45 mg/kg)-induced type 2 diabetic rat model [64]. The above research results have shown 
that polysaccharides from the fruiting body of $P$. linteus have a better application potential in the adjuvant therapy of type 2 diabetes. It was reported that phelligridimer $\mathrm{A}$, protocatechualdehyde, davallialactone, hypholomine B, interfungin A, and inoscavin A isolated from the fruiting body of $P$. linteus possessed significant rat lens aldose reductase and human recombinant aldose reductase inhibitory activity in vitro, with $\mathrm{IC}_{50}$ values of $0.63,4.26,20.52,0.33,0.82,1.03$, and $1.06 \mu \mathrm{M}$ and 1.37 , $7.93,35.36,0.56,1.28,1.82$, and $1.40 \mu \mathrm{M}$, respectively [65]. Protocatechualdehyde, davallialactone, and inoscavin A isolated from the fruiting body of $P$. linteus showed a significant inhibitory effect on methylglyoxal-medicated protein modification with $\mathrm{IC}_{50}$ values of $144.28,213.15$, and $158.66 \mu \mathrm{M}$, respectively [66]. Protocatechualdehyde and 5-hydroxymethyl-2-furaldehyde isolated from the fruiting body of $P$. linteus had an inhibitory effect on the oxidation of catalytic L-tyrosine with an $\mathrm{IC}_{50}$ value of 0.40 and $90.8 \mathrm{mg} / \mathrm{mL}$, respectively [67]. These findings demonstrated that protocatechualdehyde, davallialactone, hypholomine B, interfungin A, inoscavin A, and 5-hydroxymethyl-2-furaldehyde all had a potential therapeutic effect on diabetes [65-67]. The potential mechanism underlying the antidiabetic effects of $P$. linteus is presented in Figure 5.

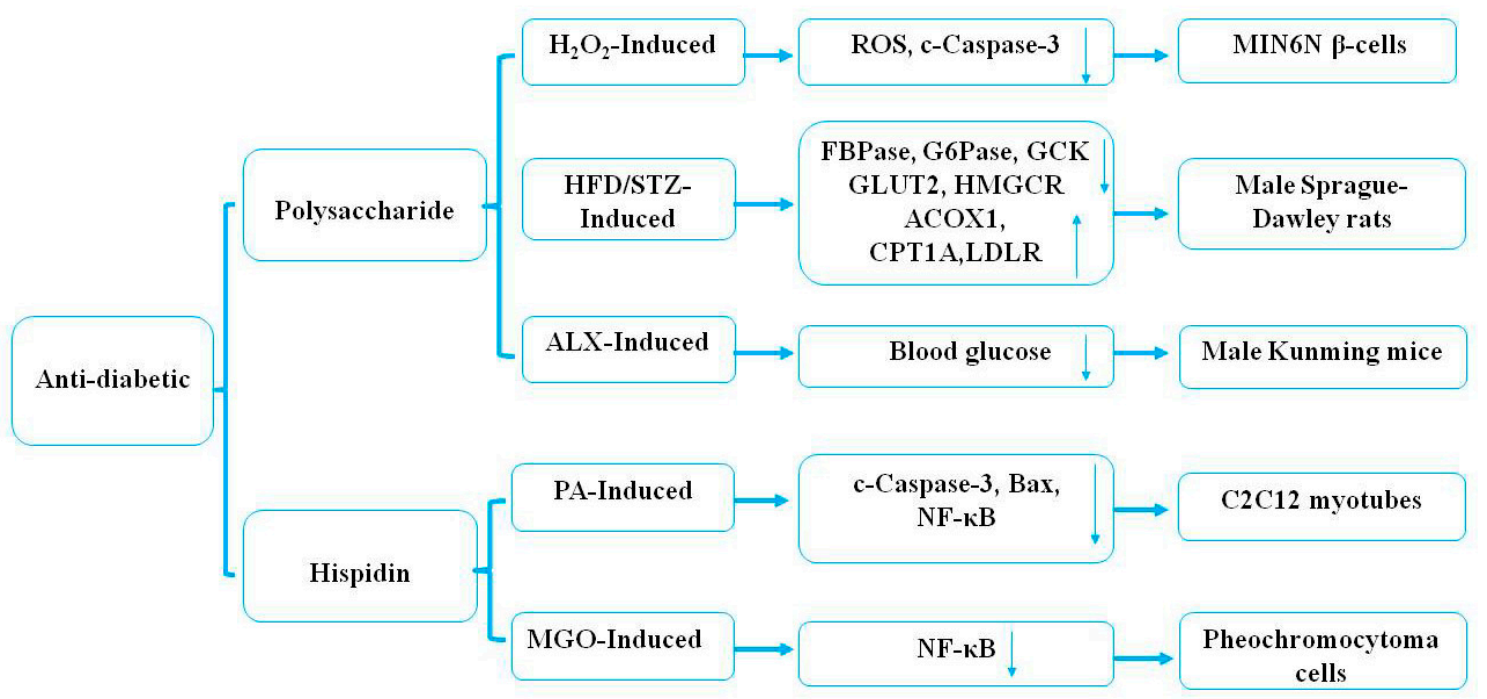

Figure 5. The potential mechanism of the antidiabetic effect of P. linteus.

\subsection{Hepatoprotective Effects}

Nowadays, polysaccharides from plants and fungi are attracting more and more attention due to their hepatoprotective activities [87]. Previous studies have revealed that a polysaccharide from the wild fruiting body of P. linteus at a dose of $50 \mathrm{mg} / \mathrm{kg}$ body weight twice a day could protect against thioacetamide (TAA)-induced liver fibrosis through the regulation of oxidative stress pathways by increasing the expression of cysteine, GSH, GSTA4, hemoglobin-heme, and by decreasing the expression of hemopexin, free-heme, free-iron, methionine, heat shock pathways, and metabolic pathways for amino acids and nucleic acids in rats [68]. The studies presented here demonstrated that ethanol extracts of $P$. linteus at a dose of $20 \mathrm{mg} / \mathrm{kg}$ exhibited a protective effect against liver injury induced by dimethyl nitrosamine (DMN) in hepatic fibrosis Wistar rats. Furthermore, phellinulin A, phellinulin $\mathrm{D}$, phellinulin E, phellinulin F, phellinulin $\mathrm{G}$, phellinulins $\mathrm{H}$, phellinulin I, phellinulin $\mathrm{K}$, phellinulin $\mathrm{M}$, phellinulin $\mathrm{N}$, phellilin $\mathrm{C}$, and $\gamma$-ionylideneacetic acid from the mycelium of $P$. linteus all showed inhibitory activities at a concentration of $40 \mu \mathrm{M}$ against activated rat hepatic stellate cells (HSCs), with inhibition rates of $67.2 \%, 4.2 \%, 23.6 \%, 26.7 \%, 15.2 \%, 60.6 \%, 50.9 \%, 67.9 \%, 56.4 \%, 47.2 \%, 24.2 \%$, and $39.7 \%$, respectively, compared with silymarin (36.4\%) as a positive control [69]. Above all, P. linteus has traditionally been used as a dietary supplement or traditional Chinese medicine to treat hepatitis, and the above studies might provide a scientific explanation underlying the traditional application. 


\subsection{Neuroprotective Effects}

Recently, researchers have carried out some investigations on P. linteus extracts used in the central nervous system. Polysaccharides from the fruiting body of $P$. linteus have played an important role in age-related neurodegenerative diseases [70]. These findings suggested that polysaccharides (200, $375,750 \mu \mathrm{g} / \mathrm{mL}$ ) of $P$. linteus treated for $24 \mathrm{~h}$ induced human leukemia cell apoptosis by increasing the expression of ROS and MMP in THP-1 monocytes in a dose-dependent manner [70]. Later, another interesting study reported that inotilone and 4-(3,4-dihydroxyphenyl)-3-buten-2-one of $P$. linteus exhibited potent neuraminidase inhibitory activity [71]. These preliminary analyses have shown that ethyl acetate extracts $(0.1-5 \mu \mathrm{g} / \mathrm{mL})$ of $P$. linteus had dose-dependent neuroprotective effects on oxidative stress $\left(\mathrm{H}_{2} \mathrm{O}_{2}\right)$-induced apoptosis through inhibiting the cleavage of caspase-3, PARP, and MAPKs by suppressing the level of ROS and increasing the expression of HO-1, CAT, GPx-1, and SOD in SK-N-MC cells [71]. However, P. linteus extracts should be investigated in an in vivo model in order to test their potential to prevent or ameliorate neurodegenerative diseases.

\subsection{Others}

Water extracts $(1.725 \mathrm{~mL} / \mathrm{kg} / \mathrm{d})$ from the fruiting body of $P$. linteus were reported to exhibit a significant therapeutic effect on prostatitis after 30 days through inhibiting benign prostatic hyperplasia by suppressing the dihydrotestosterone activity of testosterone involved in the conversion by enzyme 5-reductase in vivo compared with finasteride $(1 \mathrm{~mL} / \mathrm{kg} / \mathrm{d})$ as a positive control [88]. Previous investigations indicated that hispidin $(3,10,30 \mu \mathrm{M})$ of $P$. linteus could protect cardiomyoblast cells against $\mathrm{H}_{2} \mathrm{O}_{2}$-induced apoptosis through suppressing the Akt/GSK-3 $\beta$ and ERK1/2 signaling pathway by inhibiting the expression of caspase- 3 and Bax and increasing the expression of Bcl-2 in $\mathrm{H} 9 \mathrm{c} 2$ cardiomyoblast cells in a dose-dependent manner [78]. Polysaccharides of P. linteus at doses of $0,5,10$, and $20 \mu \mathrm{g} / \mathrm{mL}$ could prevent atherosclerosis through increasing cholesterol efflux by the PPAR- $\gamma /$ adenosine 5'-triphosphate (ATP)-binding cassette transporter A1 (ABCA1)/ATP-binding cassette G1 (ABCG1) signaling pathway in oxidized low-density lipoprotein-loaded THP-1 macrophages, while polysaccharides $(100 \mu \mathrm{g} / \mathrm{mL})$ of $P$. linteus reduced cholesterol efflux by inducing mitochondrial dysfunction and oxidative stress [89]. Furthermore, the studies have clearly revealed that 4-(3,4-dihydroxyphenyl)-3-buten-2-one (1, 5, $10 \mu \mathrm{g} / \mathrm{kg})$ effectively prevented naproxen-induced gastric antral ulcers in rats by the prevention of lipid peroxidation and the activation of radical-scavenging enzymes in a dose-dependent manner [79]. The 28-day oral administration of extracts (3\%) from the mycelium of $P$. linteus against ultraviolet B- induced hyperpigmentation due to the reduced melanin pigment content and PI3K/Akt/glycogen synthase kinase-3beta (GSK3 $\beta$ ) phosphorylation, indicating that the P. linteus extracts possessed anti-pigmentation effects in B16F0 melanoma cells compared with arbutin $(2 \%)$ as a positive control [90]. Furthermore, two novel stereoisomers of furan derivatives, phellinusfurans A and B, which were isolated from the fruiting body of $P$. linteus, showed a strong anti-complementary effect with $\mathrm{IC}_{50}$ values of 33.6 and $33.7 \mu \mathrm{M}$, respectively, compared with rosmarinic acid $\left(\mathrm{IC}_{50} 180 \mu \mathrm{M}\right)$ that was used as a positive control [80]. In brief, P. linteus has shown various pharmacological benefits and can be used as an alternative or an adjuvant treatment for a variety of diseases.

\section{Safety}

Previous studies have indicated that polysaccharides of $P$. linteus administered at a dose of $200 \mathrm{mg} / \mathrm{kg}$ for 30 days did not significantly enhance the level of ALT and AST in serum, LPO in the liver and kidney, nor did it display toxicity [34]. An acute toxicity study has demonstrated that the mycelium of P. linteus, in combination with Inonotus obliquus, Antrodia camphorata, and Ganoderma lucidum ethanol extracts, given orally at a dose of $1000 \mathrm{mg} / \mathrm{kg} / \mathrm{d}$ for 14 days did not exhibit any mortality or signs of toxicity compared with the vehicle control group [48]. However, it has not been reported which major monomer components from the mycelium of $P$. linteus produce bioactive activities and 
synergistic effects with the mycelium of three other fungi. Studies have evaluated ethanol extracts of $P$. linteus administration at a dose of $400 \mathrm{mg} / \mathrm{kg}$ for 23 days, which significantly exhibited a synergistic anticancer effect and had no adverse effect [51]. Compared to the levels in whole P. linteus, $\beta$-glucan $(29.20 \mathrm{mg} / \mathrm{g})$ showed a synergistic anticancer effect by overcoming cetuximab resistance. Thus, the results concluded that the administration of extracts from the mycelium of $P$. linteus for 23 days did not cause obvious complications. However, going through the available literature, it can be concluded that there is a lack of chronic toxicity studies, and there are still research gaps with regard to its mode of action and its pharmaceutical standardization.

\section{Conclusions and Future Perspectives}

$P$. linteus is one of the most important and frequently used traditional fungal medicines. It has been traditionally used to consolidate channels for hemostasis, remove blood-arthralgia consumption, relieve abdominal pain, and treat chronic diarrhea in China. Recently, P. linteus has attracted increasing scientific interest. Furthermore, a variety of functional supplements made with $P$. linteus have been developed in China, Japan, and Korea. However, certain aspects still need to be further studied and explored.

It is common knowledge that the bioactive compounds in both fruiting bodies and mycelial extracts of $P$. linteus produce beneficial responses regarding human health. Moreover, several studies have been published where $P$. linteus shows multiple functions against various diseases, especially against various types of cancer. The results indicated that polysaccharides and hispolon from $P$. linteus could become potential candidates for the treatment of various cancers in the future. However, there is no uniformity or predictability in terms of the bioactive compounds and the mechanism of biological activities of $P$. linteus. Therefore, further studies should focus on the relationship between the structure and the antitumor activity, clarify their anticancer mechanisms at the molecular level, and improve the different biological activities by means of the chemical modification of $P$. linteus for its safe application in human healthcare [9]. In addition, the relationship between the structural characteristics of homogeneous polysaccharides and the bioactivity of $P$. linteus also needs to be explored and illustrated. Furthermore, the biological characteristics of $P$. linteus are well understood, but most of the current studies are limited to the crude extract and a small amount of pure isolated compounds. These findings have concluded that many bioactive compounds are yet to be identified. Therefore, much research needs to be conducted in plant identification, extraction, isolation, and identification of other bioactive compounds to fully confirm its traditional uses and provide evidence to rationalize its use in humans. Finally, modern pharmacological studies have indicated that $P$. linteus has a number of biological and pharmacological activities, including anti-inflammatory, immunomodulatory, antioxidative, antimicrobial, and antiviral activities, as well as anticancer, hypoglycemic, hepatoprotective, and neuroprotective effects. Therefore, there is an urgent need to evaluate its safety and efficacy to ensure its clinical application.

Author Contributions: W.C. collated documents and wrote the manuscript; H.T. and X.Z. performed the arrangement of pictures; H.Z., Y.L., and L.X. contributed significantly to the analysis and manuscript preparation.

Funding: This work was supported by the Project of State Administration of Traditional Chinese Medicine National Chinese Medicine Resources Census (NO.GZY-KJS-2018-004).

Conflicts of Interest: The authors declare no conflict of interest.

\section{Abbreviations}

The following abbreviations are used in the manuscript: 
P. linteus Phellinus linteus

5-Fu 5-Fluorouracil

ABCA1 Adenosine 5' -triphosphate (ATP) binding cassette transporterA1

ABCG1 ATP-binding cassette G1

ABTS 2,2'-azino-bis(3-ethylbenzothiazoline-6-sulfonic acid

ACOX1 Acyl-CoA oxidase 1

AKT Protein kinase B

ALX Alloxan

AMG Aminoguanidine

AP-1 Activator protein-1

ARE Antioxidant response element

$\mathrm{BDE}_{\mathrm{d}} \quad$ Bond dissociation enthalpy

CAT Catalase

CDK2 Cyclin-dependent kinases

CHOP Kinase-homologous protein

DMN Dimethylnitrosamine

DOX Doxorubicin

Cox-2 Cyclooxygenase-2

CPT 11 Camptothecin 11

DBL 3,4-dihydroxybenzalacetone

DPPH 2,2-diphenyl-1-picrylhydrazyl

DSS Dextran sodium sulfate

EMT epithelial-mesenchymal transition

EPA Epalrestat

ERK Extracellular regulated protein kinase

FAK Focal adhesion kinase

FRAP Ferric reducing ability of plasma

Gab2 GRB2-associated-binding protein 2

GPx Glutathione peroxidase

GSH Glutathione

GSK3 $\beta \quad$ Glycogen synthase kinase-3beta

HCC Hepatocellular carcinoma

HFD High-fat high-fructose diet

HO-1 Heme oxygenase-1

HSCs Hepatic stellate cells

$\mathrm{IC}_{50} \quad$ Half maximal inhibitory concentration

IFN- $\gamma \quad$ Interferon-gamma

IgE Immunoglobulin $\mathrm{E}$

IL-1 $\beta \quad$ Interleukin IL-1 $\beta$

IL-6 Interleukin IL-6

iNOS Nitric oxide synthase

KRAS Kirsten rat sarcoma viral oncogene homolog

LNCaP Prostate cancer metastasized to lymph node

LPS Lipopolysaccharides

LPA Lipoteichoic acid

MAPKs Mitogen-activated protein kinases

MDA Malondialdehyde

MITF Microphthalmia-associated transcription factor

MIC Minimum inhibition concentration

MMP-9 Matrix metalloproteinase-9

$\alpha$-MSH $\alpha$-melanocyte-stimulating hormone

NO Nitric oxide

Nrf2 NF-E2-related factor 2

NF-kB Nuclear factor kappa beta 


$\begin{array}{ll}\text { PA } & \text { Palmitate } \\ \text { PARP } & \text { Poly ADP-Ribose Polymerase } \\ \text { PC-3 } & \text { Prostate cancer metastasized to bone } \\ \text { PCET } & \text { Proton-coupled electron transfer } \\ \text { PEMs } & \text { Peritoneal exudate macrophages } \\ \text { PI3K } & \text { Phosphoinositide-3-kinase } \\ \text { PKC } & \text { Protein kinase C } \\ \text { PKC } \delta & \text { Phosphorylation of protein kinase C } \delta \\ \text { PPAR } & \text { Peroxisome proliferator-activated receptor } \\ \text { PPI } & \text { Protein-protein interaction } \\ \text { PTK } & \text { Protein tyrosine kinase } \\ \text { ROS } & \text { Reactive oxygen species } \\ \text { SOD } & \text { Superoxide dismutase } \\ \text { STZ } & \text { Streptozotocin } \\ \text { Syk } & \text { Spleen tyrosine kinase } \\ \text { TAA } & \text { Thioacetamide } \\ \text { TB } & \text { Tumor-bearing } \\ \text { TCM } & \text { Traditional Chinese medicine } \\ \text { TEAC } & \text { Trolox-equivalent antioxidant capacity } \\ \text { TGF- } \beta & \text { Transforming growth factor } \beta \\ \text { Th1 } & \text { T helper } 1 \\ \text { Th2 } & \text { T helper } 2 \\ \text { TLR4 } & \text { Toll-like receptor } 4 \\ \text { TNF- } \alpha & \text { Tumor necrosis factor } \\ \text { TRAIL } & \text { Tumor necrosis factor-related apoptosis-inducing ligand }\end{array}$

\section{References}

1. Zhu, T.; Kim, S.H.; Chen, C.Y. A medicinal mushroom: Phellinus Linteus. Curr. Med. Chem. 2008, 15, 1330-1335. [CrossRef]

2. Luan, Y.; Hou, W.S. Notes on Shen Nong's Herbal Classic; People's Military Medical Publishing House: Beijing, China, 2010; pp. 218-219.

3. Su, J. New Compendium of Materia Medica; Anhui Science \& Technology Publishing House: Hefei, China, 1981; p. 353.

4. Li, S.H. Compendium of Materia Medica; People's Medical Publishing House: Beijing, China, 2004; pp. $1713-1714$.

5. Dai, Y.C.; Xu, M.Q. Studies on the medicinal polypore, Phellinus baumii and its kin, Phellinus linteus. Mycotaxon 1998, 67, 191-200.

6. Kim, B.C.; Jeon, W.K.; Hong, H.Y.; Jeon, K.B.; Hahn, J.H.; Kim, Y.M.; Numazawa, S.; Yosida, T.; Park, E.H.; Lim, C.J. The anti-inflammatory activity of Phellinus linteus (Berk. \& M.A. Curt.) is mediated through the

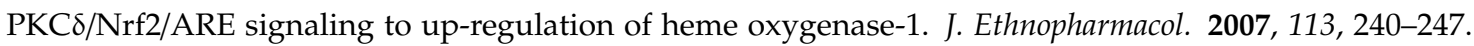
[PubMed]

7. Lin, C.J.; Lien, H.M.; Chang, H.Y.; Huang, C.L.; Liu, J.J.; Chang, Y.C.; Chen, C.C.; Lai, C.H. Biological evaluation of Phellinus linteus-fermented broths as anti-inflammatory agents. J. Biosci. Bioeng. 2014, 118, 88-93. [CrossRef] [PubMed]

8. Song, M.J.; Park, H.J. Anti-inflammatory effect of Phellinus linteus grown on germinated brown rice on dextran sodium sulfate-induced acute colitis in mice and LPS-activated macrophages. J. Ethnopharmacol. 2014, 154, 311-318. [CrossRef]

9. Yang, L.Y.; Shen, S.C.; Cheng, K.T.; Subbaraju, G.V.; Chien, C.C.; Chen, Y.C. Hispolon inhibition of inflammatory apoptosis through reduction of iNOS/NO production via HO-1 induction in macrophages. J. Ethnopharmacol. 2014, 156, 61-72. [CrossRef] [PubMed]

10. Wu, M.S.; Chien, C.C.; Cheng, K.T.; Subbaraju, G.V.; Chen, Y.C. Hispolon suppresses LPS- or LTA-induced iNOS/NO production and apoptosis in BV-2 microglial cells. Am. J. Chin. Med. 2017, 45, 1649-1666. [CrossRef] 
11. Park, H.J. Anti-allergic and anti-inflammatory activity of Phellinus linteus grown on panax ginseng. Food Sci. Biotechnol. 2017, 26, 467-472. [CrossRef] [PubMed]

12. Chao, W.; Deng, J.S.; Huang, S.S.; Li, P.Y.; Liang, Y.C.; Huang, G.J. 3, 4-dihydroxybenzal-acetone attenuates lipopolysaccharide-induced inflammation in acute lung injury via down-regulation of MMP-2 and MMP-9 activities through suppressing ROS-mediated MAPK and PI3K/AKT signaling pathways. Int. Immunopharmacol. 2017, 50, 77-86.

13. Hu, T.; Lin, Q.L.; Guo, T.; Yang, T.; Zhou, W.H.; Deng, X.F.; Yan, J.K.; Luo, Y.; Ju, Y.Y.; Luo, F.J. Polysaccharide isolated from Phellinus linteus mycelia exerts anti-inflammatory effects via MAPK and PPAR signaling pathways. Carbohydr. Polym. 2018, 200, 487-497. [CrossRef]

14. Xie,Z.L.; Wang, Y.; Huang, J.Q.; Qian, N.; Shen, G.Z.; Chen, L.H. Anti-inflammatory activity of polysaccharides from Phellinus linteus by regulating the NF- $\mathrm{kB}$ translocation in LPS-stimulated RAW264.7 macrophages. Int. Biol. Macromol. 2019, 129, 61-67. [CrossRef]

15. Kim, G.Y.; Park, S.K.; Lee, M.K.; Lee, S.H.; Oh, Y.H.; Kwak, J.Y.; Yoon, S.; Lee, J.D.; Park, Y.M. Proteoglycan isolated from Phellinus linteus activates murine B lymphocytes via protein kinase $\mathrm{C}$ and protein tyrosine kinase. Int. Immunopharmacol. 2003, 3, 1281-1292. [CrossRef]

16. Oh, G.S.; Lee, M.S.; Pae, H.K.; Kwon, J.; Lee, S.S.; Jeong, J.G.; Shin, M.K.; Kwon, T.O.; Chung, H.T. Effects of oral administration of Phellinus Linteus on the production of Th1- and Th2-type cytokines in mice. Immunopharmacol. Immunotoxicol. 2006, 28, 281-293. [CrossRef]

17. Kim, G.Y.; Lee, J.Y.; Lee, J.O.; Rru, C.H.; Choi, B.T.; Jeong, Y.K.; Lee, K.W.; Jeong, S.C.; Choi, Y.H. Partial characterization and imunostimulatory effect of a novel polysaccharide-protein complex extracted from Phellinus Linteus. Biosci. Biotechnol. Biochem. 2006, 70, 1218-1226. [CrossRef]

18. Suabjakyong, P.; Nishimura, K.; Toida, T.; Van Griensven, L.J. Structural characterization and immunomodulatory effects of polysaccharides from Phellinus linteus and Phellinus igniarius on the IL-6/IL-10 cytokine balance of the mouse macrophage cell lines (RAW264.7). Food. Funct. 2015, 6, 2834-2844. [CrossRef]

19. Lin, C.J.; Lien, H.M.; Lin, H.J.; Huang, C.L.; Kao, M.C.; Chen, Y.A.; Wang, C.K.; Chang, H.Y.; Chang, Y.K.; Wu, H.S.; et al. Modulation of T cell response by Phellinus linteus. J. Biosci. Bioeng. 2016, 121, 84-88. [CrossRef]

20. Gao, C.P.; Zhong, L.F.; Jiang, L.P.; Geng, C.Y.; Yao, X.F.; Cao, J. Phellinus linteus mushroom protects against tacrine-induced mitochondrial impairment and oxidative stress in HepG2 cells. Phytomedicine 2013, 20, 705-709. [CrossRef]

21. Wang, Z.B.; Pei, J.J.; Ma, H.L.; Cai, P.F.; Yan, J.K. Effect of extraction media on preliminary characterizations and antioxidant activities of Phellinus linteus polysaccharides. Carbohydr. Polym. 2014, 109, 49-55. [CrossRef]

22. Chen, W.; Shen, Y.; Su, H.M.; Zheng, X.D. Hispidin derived from Phellinus linteus affords protection against acrylamide-induced oxidative stress in Caco-2 cells. Chem. Biol. Inter. 2014, 219, 83-89. [CrossRef]

23. Anouar, E.H.; Shah, S.A.; Hassan, N.B.; Moussaoui, N.E.; Ahmad, R.; Zulkefeli, M.; Weber, J.F. Antioxidant activity of hispidin oligomers from medicinal fungi: ADFT study. Molecules 2014, 19, 3489-3507. [CrossRef]

24. Lee, M.S.; Hwang, B.S.; Lee, I.K.; Seo, G.S.; Yun, B.S. Chemical constituents of the culture broth of Phellinus linteus and their antioxidant activity. Mycobiology 2015, 43, 43-48. [CrossRef]

25. Yan, J.K.; Wang, Y.Y.; Wang, Z.B.; Ma, H.L.; Pei, J.J.; Wu, J.Y. Structure and antioxidative property of a polysaccharide from an ammonium oxalate extract of Phellinus linteus. Inter. J. Biol. Macromol. 2016, 91, 92-123. [CrossRef]

26. Kong, S.Z.; Li, J.C.; Li, S.D.; Liao, M.N.; Li, C.P.; Zheng, P.J.; Guo, M.H.; Tan, W.X.; Zheng, Z.H.; Hu, Z. Anti-aging effect of chitosan oligosaccharide on D-galactose-induced subacute aging in mice. Mar. Drugs 2018, 16, 181. [CrossRef]

27. Hur, J.M.; Yang, C.H.; Han, S.H.; Lee, S.H.; You, Y.O.; Park, J.C.; Kim, K.J. Antibacterial effect of Phellinus linteus against methicillin-resistant Staphylococcus aureus. Fitoterapia 2004, 75, 603-605. [CrossRef]

28. Cho, J.Y.; Kwon, Y.J.; Sohn, M.J.; Seok, S.J.; Kim, W.G. Phellinstatin, a new inhibitor of enoyl-ACP reductase produced by the medicinal fungus Phellinus linteus. Bioorg. Med. Chem. Lett. 2011, 21, 1716-1718. [CrossRef]

29. Ota, K.; Yamazaki, I.; Saigoku, T.; Fukui, M.; Miyata, T.; Kamaike, K.; Shirahata, T.; Mizuno, F.; Asada, Y.; Hirotani, M.; et al. Phellilane L, sesquiterpene metabolite of Phellinus linteus: Isolation, structure elucidation, and asymmetric total synthesis. J. Org. Chem. 2017, 82, 12377-12385. [CrossRef] 
30. Shirahata, T.; Ino, C.; Mizuno, F.; Asada, Y.; Hirotani, M.; Petersson, G.A.; Ōmura, S.; Yoshikawa, T.; Kobayashi, Y. $\gamma$-Ionylidene-type sesquiterpenoids possessing antimicrobial activity against Porphyromonas gingivalis from Phellinus linteus and their absolute structure determination. J. Antibiot. 2017, 70, 695-698. [CrossRef]

31. Yeo, W.H.; Hwang, E.I.; So, S.H.; Lee, S.M. Phellinone, a new furanone derivative from the Phellinus linteus KT\&G PL-2. Arch. Pharm. Res. 2007, 30, 924-926.

32. Ichinohe, T.; Ainai, A.; Nakamura, T.; Akiyama, Y.; Maeyama, J.J.; Odagiri, T.; Tashiro, M.; Takahashi, H.; Sawa, H.; Tamura, S.I.; et al. Induction of cross-protective immunity against influenza a virus H5N1 by an intranasal vaccine with extracts of mushroom mycelia. J. Med. Virol. 2010, 82, 128-137. [CrossRef]

33. Hwang, B.S.; Lee, M.S.; Lee, S.W.; Lee, I.K.; Seo, G.S.; Choi, H.J.; Yun, B.S. Neuraminidase inhibitors from the fermentation broth of Phellinus linteus. Mycobiology 2014, 42, 189-192. [CrossRef]

34. Zhong, S.; Ji, D.F.; Li, Y.G.; Lin, T.B.; Lv, Z.Q.; Chen, H.P. Activation of P27kip1-cyclin D1/E-CDK2 pathway by polysaccharide from Phellinus linteus leads to S-phase arrest in HT-29 cells. Chem. Biol. Interact. 2013, 206, 222-229. [CrossRef] [PubMed]

35. Li, Y.C.; Ji, D.F.; Zhong, S.; Liu, P.G.; Lv, Z.Q.; Zhu, J.X.; Chen, J.E.; Chen, H.P. Polysaccharide from Phellinus linteus induces S-phase arrest in HepG2 cells by decreasing calreticulin expression and activating the P27kip1-cyclin A/D1/E-CDK2 pathway. J. Ethnopharmacol. 2013, 150, 187-195. [CrossRef] [PubMed]

36. Pei, J.J.; Wang, Z.B.; Ma, H.L.; Yan, J.K. Structural features and antitumor activity of a novel polysaccharide from alkaline extract of Phellinus linteus mycelia. Carbohyd. Polym. 2015, 115, 472-477. [CrossRef] [PubMed]

37. Mei, Y.X.; Zhu, H.; Hu, Q.M.; Liu, Y.Y.; Zhao, S.M.; Peng, N.; Liang, Y.X. A novel polysaccharide from mycelia of cultured Phellinus linteus displays antitumor activity through apoptosis. Carbohyd. Polym. 2015, 124, 90-97. [CrossRef]

38. Chai, Y.Y.; Wang, G.B.; Fan, L.L.; Zhao, M. A proteomic analysis of mushroom polysaccharide-treated HepG2 cells. Sci. Rep. 2016, 6, 23565-23576. [CrossRef] [PubMed]

39. Yu, T.Q.; Ganapathy, S.; Shen, L.; Peng, B.; Kim, S.H.; Makriyannis, A.; Chen, C.Y. A lethal synergy induced by phellinus linteus and camptothecin11 in colon cancer cells. Oncotarget 2018, 9, 6308-6319. [CrossRef]

40. Jeon, T.I.; Jung, C.H.; Cho, J.Y.; Park, D.K.; Moon, J.H. Identification of an anticancer compound against HT-29 cells from Phellinus linteus grown on germinated brown rice. Asian Pac. J. Trop. Biomed. 2013, 3, 785-789. [CrossRef]

41. Chen, Y.C.; Chang, H.Y.; Deng, J.S.; Chen, J.J.; Huang, S.S.; Lin, I.H.; Kuo, W.L.; Chao, W.; Huang, G.J. Hispolon from Phellinus linteus induces G0/G1 cell cycle arrest and apoptosis in NB4 human leukaemia cells. Am. J. Chin. Med. 2013, 41, 1439-1457. [CrossRef] [PubMed]

42. Chen, Y.S.; Lee, S.M.; Lin, C.C.; Liu, C.Y. Hispolon decreases melanin production and induces apoptosis in melanoma cells through the downregulation of tyrosinase and microphthalmia-associated transcription factor (MITF) expressions and the activation of Caspase-3, -8 and -9. Int. J. Mol. Sci. 2014, 15, 1201-1215. [CrossRef]

43. Hsieh, M.J.; Chien, S.Y.; Chou, Y.E.; Chen, C.J.; Chen, J.; Chen, M.K. Hispolon from Phellinus linteus possesses mediate caspases activation and induces human nasopharyngeal carcinomas cells apoptosis through ERK1/2, JNK1/2 and p38 MAPK pathway. Phytomedicine 2014, 21, 1746-1752. [CrossRef] [PubMed]

44. Jang, E.H.; Jang, S.Y.; Cho, I.H.; Hong, D.; Jung, B.; Park, M.J.; Kim, J.K. Hispolon inhibits the growth of estrogen receptor positive human breast cancer cells through modulation of estrogen receptor alpha. Biochem. Biophys. Res. Commun. 2015, 463, 917-922. [CrossRef]

45. Kim, J.H.; Kim, Y.C.; PARK, B. Hispolon from Phellinus linteus induces apoptosis and sensitizes human cancer cells to the tumor necrosis factor-related apoptosis-inducing ligand through upregulation of death receptors. Oncol. Rep. 2016, 35, 1020-1026. [CrossRef]

46. Hong, D.; Park, M.; Jang, E.H.; Jung, B.; Kim, N.J.; Kim, J.H. Hispolon as an inhibitor of TGF- $\beta$-induced epithelial-mesenchymal transition in human epithelial cancer cells by co- regulation of TGF- $\beta$-Snail/Twist axis. Oncol. Lett. 2017, 14, 4866-4872. [CrossRef]

47. Arcella, A.; Oliva, M.A.; Sanchez, M.; Staffieri, S.; Esposito, V.; Giangaspero, F.; Cantore, G. Effects of hispolon on glioblastoma cell growth. Environ. Toxicol. 2017, 32, 2113-2123. [CrossRef]

48. Park, H.J. CARI III inhibits tumor growth in a melanoma-bearing mouse model through induction of G0/G1 cell cycle arrest. Molecules 2014, 19, 14383-14395. [CrossRef] 
49. Konno, S.; Chu, K.; Feuer, N.; Phillips, J.; Choudhury, M. Potent anticancer effects of bioactive mushroom extracts (Phellinus linteus) on a variety of human cancer cells. J. Clin. Med. Res. 2015, 7, 76-82. [CrossRef]

50. Lee, W.Y.; Hsu, K.F.; Chiang, T.A.; Chen, C.J. Phellinus Linteus extract induces autophagy and synergizes with 5-Fluorouracil to inhibit breast cancer cell growth. Nutr. Cancer 2015, 67, 275-284. [CrossRef]

51. Park, H.J.; Park, J.B.; Lee, S.J.; Song, M.J. Phellinus linteus grown on germinated brown rice increases cetuximab sensitivity of KRAS-mutated colon cancer. Int. J. Mol. Sci. 2017, 18, 1746. [CrossRef]

52. Lee, S.H.; Hwang, H.K.; Kang, C.M.; Lee, W.J. Potential impact of Phellinus linteus on adherence to adjuvant treatment after curative resection of pancreatic ductal adenocarcinoma: Outcomes of a propensity score-matched analysis. Integr. Cancer Ther. 2019, 18, 1-9. [CrossRef]

53. Chao, W.; Deng, J.S.; Li, P.Y.; Liang, Y.C.; Huang, G.J. 3,4-Dihydroxybenzalactone suppresses human non-small cell lung carcinoma cells metastasis via suppression of epithelial to mesenchymal transition, ROS-mediated PI3K/AKT/MAPK/MMP and NFKB signaling pathways. Molecules 2017, 22, 537. [CrossRef]

54. Huang, S.C.; Kuo, P.C.; Hung, H.Y.; Pan, T.L.; Chen, F.A.; Wu, T.S. Ionone derivatives from the mycelium of Phellinus linteus and the inhibitory effect on activated rat hpatic stellate cells. Int. J. Mol. Sci. 2016, 17, 681. [CrossRef] [PubMed]

55. Chandimali, N.; Huynh, D.L.; Jin, W.Y.; KWON, T. Combination effects of hispidin and gemcitabine via inhibition of stemness in pancreatic cancer stem cells. Anticancer Res. 2018, 38, 3967-3975. [CrossRef] [PubMed]

56. Nagatsu, A.; Itoh, S.; Tanaka, R.; Kato, S.; Haruna, M.; Kishimoto, K.; Hirayama, H.; Goda, Y.; Mizumasa, H.; Ogihara, Y. Identification of novel substituted fused aromatic compounds, meshimakobnol A and B, from natural Phellinus linteus fruit body. Tetrahedron. Lett. 2004, 45, 5931-5933. [CrossRef]

57. Kojima, K.; Ohno, T.; Inoue, M.; Mizukami, H.; Nagatsu, A. Phellifuropyranone A: A new furopyranone compound isolated from fruit bodies of wild Phellinus linteus. Chem. Pharm. Bull. 2008, 56, 173-175. [CrossRef] [PubMed]

58. Kim, H.M.; Kang, J.S.; Kim, J.Y.; Park, S.K.; Kim, H.S.; Lee, Y.J.; Yun, J.; Hong, J.T.; Kim, Y.S.; Han, S.B. Evaluation of antidiabetic activity of polysaccharide isolated from Phellinus linteus in non-obese diabetic mouse. Int. Immunopharmacol. 2010, 10, 72-78. [CrossRef]

59. Lee, J.H.; Lee, J.S.; Kim, Y.R.; Jung, W.C.; Lee, K.E.; Lee, S.Y.; Hong, E.K. Hispidin isolated from Phellinus linteus protects against hydrogen peroxide-induced oxidative stress in pancreatic MIN6N b-cells. J. Med. Food 2011, 14, 1431-1438. [CrossRef] [PubMed]

60. Zhao, C.; Liao, Z.S.; Wu, X.Q.; Liu, Y.L.; Liu, X.Y.; Lin, Z.X.; Huang, Y.F.; Liu, B. Isolation, purification, and structural features of a polysaccharide from Phellinus linteus and its hypoglycemic effect in alloxan-induced diabetic mice. J. Food. Sci. 2014, 79, 1002-1010.

61. Park, J.M.; Lee, J.S.; Song, J.E.; Sim, Y.C.; Ha, S.J.; Hong, E.K. Cytoprotective effect of hispidin against palmitate-induced lipotoxicity in C2C12 myotubes. Molecules 2015, 20, 5456-5467. [CrossRef]

62. Song, T.Y.; Yang, N.C.; Chen, C.L.; Thi, T.L. Protective effects and possible mechanisms of ergothioneine and hispidin against methylglyoxal-induced injuries in rat pheochromocytoma cells. Oxid. Med. Cell. Longev. 2017, 2017, 1-10. [CrossRef]

63. Feng, H.; Zhang, S.J.; Man-Fan Wan, J.; Gui, L.F.; Ruan, M.C.; Li, N.; Zhang, H.Y.; Liu, Z.G.; Wang, H.L. Polysaccharides extracted from Phellinus linteus ameliorate high-fat high-fructose diet induced insulin resistance in mice. Carbohydr. Polym. 2018, 200, 144-153. [CrossRef]

64. Liu, Y.Y.; Wang, C.R.; Li, J.S.; Mei, Y.X.; Liang, Y.X. Hypoglycemic and hypolipidemic effects of Phellinus Linteus mycelial extract from solid-state culture in a rat model of type 2 diabetes. Nutrients 2019, 11, 296. [CrossRef] [PubMed]

65. Lee, Y.S.; Kang, Y.H.; Jung, J.Y.; Kang, I.J.; Han, S.N.; Chung, J.S.; Shin, H.K.; Lim, S.S. Inhibitory constituents of aldose reductase in the fruiting body of Phellinus linteus. Biol. Pharm. Bull. 2008, 31, 765-768. [CrossRef]

66. Lee, Y.S.; Jang, Y.H.; Jung, J.Y.; Lee, S.; Ohuchi, K.; Shin, K.H.; Kang, I.J.; Park, J.H.; Shin, H.K.; Lim, S.S. Protein glycation inhibitors from the fruiting body of Phellinus linteus. Biol. Pharm. Bull. 2008, 31, 1968-1972. [CrossRef]

67. Kang, H.S.; Choi, J.H.; Cho, W.K.; Park, J.C.; Choi, J.S. A sphingolipid and tryrosinase inhibitors from the fruiting body of Phellinus linteus. Arch. Pharm. Res. 2004, 27, 742-750. [CrossRef] [PubMed]

68. Wang, H.; Wu, G.; Park, H.J.; Jiang, P.P.; Sit, W.H.; Van Griensven, L.J.; Wan, J.M. Protective effect of Phellinus linteus polysaccharide extracts against thioacetamide-induced liver fibrosis in rats: A proteomics analysis. Chin. Med. 2012, 7, 23-32. [CrossRef] 
69. Huang, S.C.; Wang, P.W.; Kuo, P.C.; Hung, H.Y.; Pan, T.L. Hepatoprotective principles and other chemical constituents from the mycelium of Phellinus linteus. Molecules 2018, 23, 1705. [CrossRef]

70. Griensven, L.J.V.; Verhoeven, H.A. Phellinus linteus polysaccharide extracts increase the mitochondrialmembrane potential and cause apoptotic death of THP-1 monocytes. Chin. Med. 2013, 8, 25-37. [CrossRef]

71. Choi, D.J.; Cho, S.; Seo, J.Y.; Lee, H.B.; Park, Y. Neuroprotective effects of the Phellinus linteus ethyl acetate extract against $\mathrm{H}_{2} \mathrm{O}_{2}$-induced apoptotic cell death of SK-N-MC cells. Nutr. Res. 2016, 36, 31-43. [CrossRef]

72. Lemieszek, M.; Rzeski, W. Anticancer properties of polysaccharides isolated from fungi of the basidiomycetes class. Contemp. Oncol. 2012, 4, 285-289. [CrossRef]

73. Meng, X.; Liang, H.; Luo, L. Antitumor polysaccharides from mushrooms: A review on the structural characteristics, antitumor mechanisms and immunomodulating activities. Carbohyd. Res. 2016, 424, 30-41. [CrossRef]

74. Sliva, D. Medicinal mushroom Phellinus linteus as an alternative cancer therapy (Review). Exp. Ther. Med. 2010, 1, 407-411. [CrossRef]

75. Lee, I.K.; Yun, B.S. Styrylpyrone-class compounds from medicinal fungi Phellinus and Inonotus spp., and their medicinal importance. J. Antibiot. 2011, 64, 349-359. [CrossRef]

76. Hsieh, P.W.; Wu, J.B.; Wu, Y.C. Chemistry and biology of Phellinus linteus. BioMedicine 2013, 3, $106-113$. [CrossRef]

77. Chen, H.; Tian, T.; Miao, H.; Zhao, Y.Y. Traditional uses, fermentation, phytochemistry and pharmacology of Phellinus linteus: A review. Fitoterapia 2016, 113, 6-26. [CrossRef]

78. Kim, D.E.; Kim, B.; Shin, H.S.; Kwon, H.J.; Park, E.S. The protective effect of hispidin against hydrogen peroxide-induced apoptosis in H9c2 cardiomyoblast cells through Akt/GSK-3 $\beta$ and ERK1/2 signaling pathway. Exp. Cell Res. 2014, 327, 264-275. [CrossRef]

79. Kim, J.H.; Kwon, H.J.; Kim, B.W. Protective effect of 4-(3,4-Dihydroxyphenyl)-3-Buten-2-One from Phellinus linteus on naproxen-induced gastric antral ulcers in rats. J. Microbiol. Biotechnol. 2016, 26, 823-828. [CrossRef]

80. Min, B.S.; Yun, B.S.; Lee, H.K.; Jung, H.J.; Jung, H.A.; Choi, J.S. Two novel furan derivatives from Phellinus linteus with anticomplement activity. Bioorg. Med. Chem. Lett. 2006, 16, 3255-3257. [CrossRef]

81. Elsayed, E.A.; El Enshasy, H.; Wadaan, M.A.; Aziz, R. Mushrooms: A potential natural source of antiinflammatory compounds for medical applications. Mediat. Inflamm. 2014, 2014, 805841-805855. [CrossRef]

82. Muszyńska, B.; Grzywacz-Kisielewska, A.; Kała, K.; Gdula-Argasińska, J. Anti-inflammatory properties of edible mushrooms: A review. Food. Chem. 2018, 243, 373-381. [CrossRef]

83. Joseph, T.P.; Chanda, W.; Padhiar, A.A.; Batool, S.; Qun, S.L.; Zhong, M.T.; Huang, M. A preclinical evaluation of the antitumor activities of edible and medicinal mushrooms: A molecular insight. Integr. Cancer Ther. 2017, 17, 200-209. [CrossRef]

84. Wang, Q.; Wang, F.; Xu, Z.H.; Ding, Z.Y. Bioactive mushroom polysaccharides: A review on monosaccharide composition, biosynthesis and regulation. Molecules 2017, 22, 955. [CrossRef]

85. Zhang, M.; Cui, S.W.; Cheung, P.C.K.; Wang, Q. Antitumor polysaccharides from mushrooms: A review on their isolation process, structural characteristics and antitumor activity. Trends Food Sci. Tech. 2007, 18, 4-19. [CrossRef]

86. Necyk, C.; Zubach-Cassano, L. Natural health products and diabetes: A practical review. Can. J. Diabetes 2017, 41, 642-647. [CrossRef]

87. Cai, L.L.; Wan, D.W.; Yi, F.L.; Luan, L.B. Purification, preliminary characterization and hepatoprotective effects of polysaccharides from dandelion root. Molecules 2017, 22, 1409-1423.

88. Kim, Y.N.; Kim, M.S.; Chun, S.S.; Choi, J.H. Effect of Phellius linteus water extract on benign prostatic hyperplasia. Nutr. Res. Pract. 2013, 7, 172-177. [CrossRef]

89. Li, X.H.; Li, Y.; Cheng, Z.Y.; Cai, X.G.; Wang, H.M. The effects of Phellinus linteus polysaccharide extracts on cholesterol efflux in oxidized low-density lipoprotein-loaded THP-1 macrophages. J. Investig. Med. 2015, 63, 752-757. [CrossRef]

90. Ahn, H.Y.; Choo, Y.M.; Cho, Y.S. Anti-pigmentation effects of eight Phellinus linteus-fermented traditional crude herbal extracts on brown guinea pigs of ultraviolet B-induced hyperpigmentation. J. Microbiol. Biotechnol. 2018, 28, 375-380. [CrossRef]

(C) 2019 by the authors. Licensee MDPI, Basel, Switzerland. This article is an open access article distributed under the terms and conditions of the Creative Commons Attribution (CC BY) license (http://creativecommons.org/licenses/by/4.0/). 